\title{
Where Have All the Women Combatants Gone? The Realities of Soviet Female Veterans in the Immediate Post World War Two Period
}

Jekaterina Tsizikova

West Virginia University

Follow this and additional works at: https://researchrepository.wvu.edu/etd

\section{Recommended Citation}

Tsizikova, Jekaterina, "Where Have All the Women Combatants Gone? The Realities of Soviet Female Veterans in the Immediate Post World War Two Period" (2011). Graduate Theses, Dissertations, and Problem Reports. 4806.

https://researchrepository.wvu.edu/etd/4806

This Thesis is protected by copyright and/or related rights. It has been brought to you by the The Research Repository @ WVU with permission from the rights-holder(s). You are free to use this Thesis in any way that is permitted by the copyright and related rights legislation that applies to your use. For other uses you must obtain permission from the rights-holder(s) directly, unless additional rights are indicated by a Creative Commons license in the record and/ or on the work itself. This Thesis has been accepted for inclusion in WVU Graduate Theses, Dissertations, and Problem Reports collection by an authorized administrator of The Research Repository @ WVU. For more information, please contact researchrepository@mail.wvu.edu. 


\title{
Where Have All the Women Combatants Gone? The Realities of Soviet Female Veterans in the Immediate Post World War Two Period
}

\author{
Jekaterina Tsizikova
}

Thesis submitted to the Eberly College of Arts and Sciences at West Virginia University in partial fulfillment of the requirements for the degree of

Master of Arts in History

\author{
Robert Blobaum, Ph.D., Chair \\ Aaslestand,Katherine, Ph.D. \\ Elizabeth Fones-Wolf, Ph.D. \\ Department of History
}

Morgantown, West Virginia

2011

Keywords: World War Two; Gender History; The Myth of the Great Patriotic War; Soviet female and male combatants; Soviet ideology; Soviet propaganda

Copyright 2011 Jekaterina Tsizikova 


\title{
Abstract
}

\section{Where Have All the Women Combatants Gone? The Realities of Soviet Female Veterans in the Immediate Post World War Two Period}

\author{
Jekaterina Tsizikova
}

Relying on numerous testimonies of Soviet women combatants, this thesis demonstrates the wartime and post-war realities of Soviet women soldiers. About a million of women combatants took an active part in the war, yet they remained in the shadow of the Great Victory of 1945. This paper explores the unwillingness of the Soviet state to recognize the contribution of Soviet women combatants in the fighting of the Second World War. Why did the myth of the Great Patriotic War exclude women? Why were some women soldiers more worthy of recognition than others? What, compared to female veterans, was the status of male veterans in the post-World War Two Soviet society?

The main findings of the thesis showed that the reasons for the marginalization of female combatants in the Soviet society include the gender ideology of the Soviet state and marginal status of women within it, the pro-natalist policies of the Soviet state in which a woman was first of all a mother and keeper of the household, and the psychological effects of war on former women combatants. Thus the ideal image of a Soviet woman was that of a mother and a housekeeper and left no room for that of a woman soldier.

The second part of this thesis compared the status of female and male veterans. The results of that comparison demonstrated that Soviet veterans of the Second World War were all neglected, regardless of their sex. It was not only women combatants who remained in the shadow of the Great Victory, but also male veterans of the Great Patriotic War were ignored and at times victimized by the Stalinist state. They did not receive any more recognition than female combatants. Maybe it seemed that they were proclaimed "heroes" more often, but in practice such proclamation brought nothing with it.

In the narrative of the Myth of the Great Patriotic War female combatants were invisible, whereas male combatants were characterless. The victory was proclaimed as a collective achievement of the Soviet state and society, and the number of recognized heroes of the Great Patriotic War remained minimal. Research on the experience of Soviet veterans remains minimal. With each passing year, veterans decrease in number. Hence there is an immediate need to conduct new research on the topic. Otherwise, the real story of these veterans will never be told. 


\section{Table of Contents}

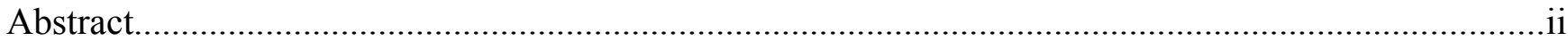

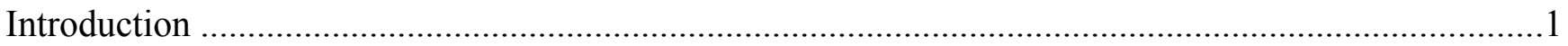

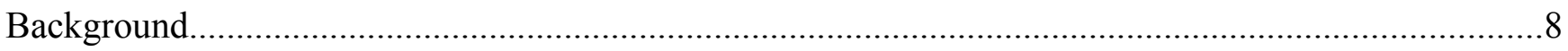

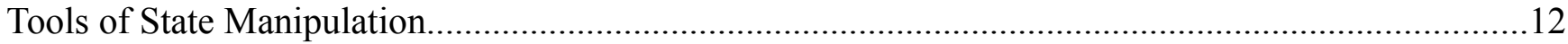

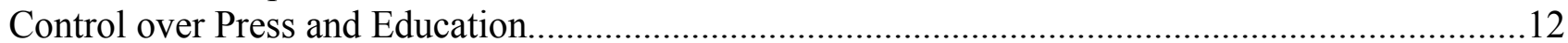

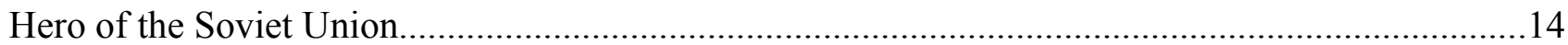

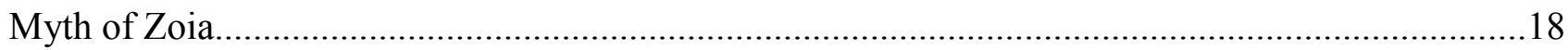

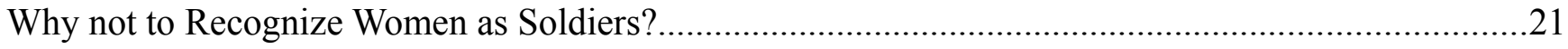

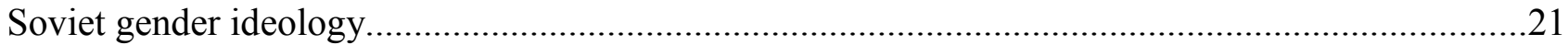

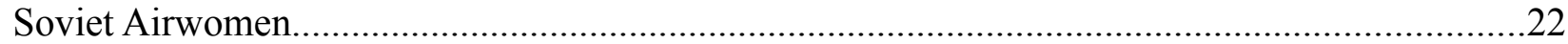

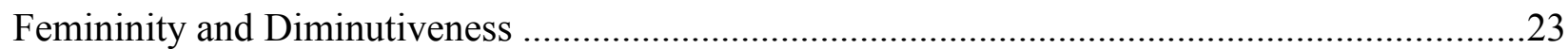

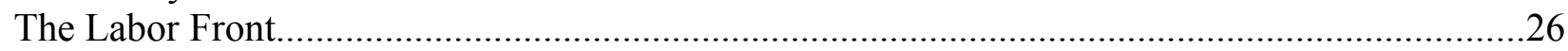

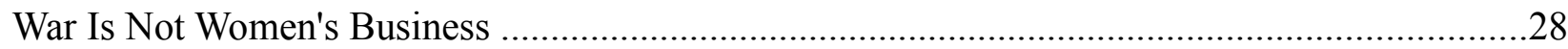

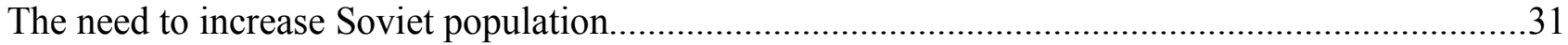

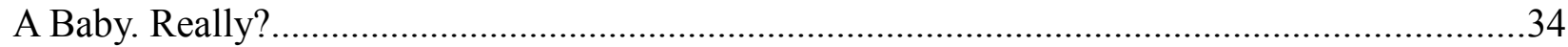

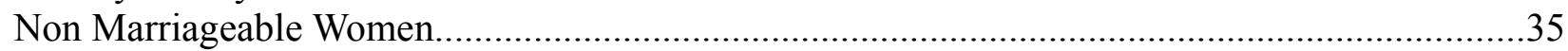

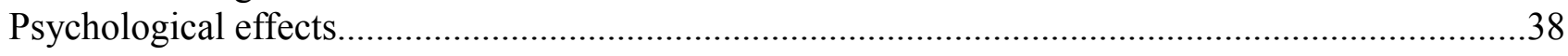

Wartime Trauma.......................................................................................................

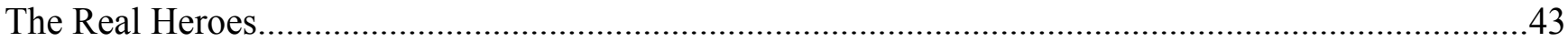

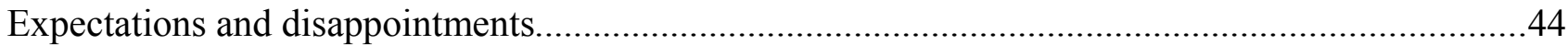

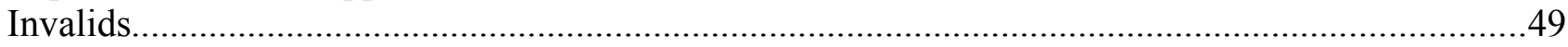

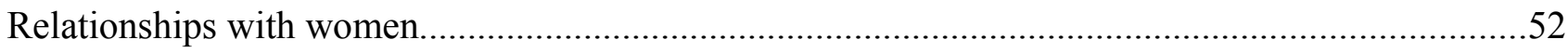

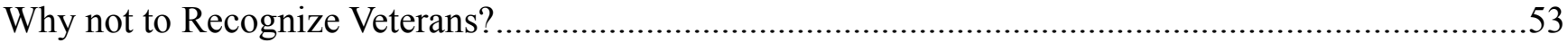

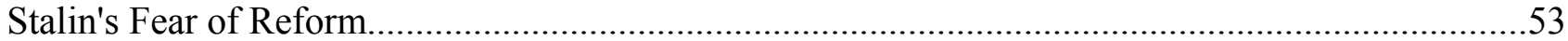

The Importance of Gender in the Context of Contemporary Conflicts................................................59

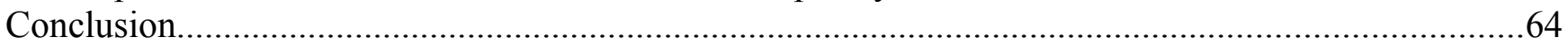

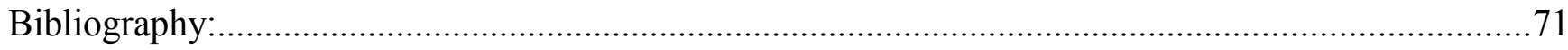

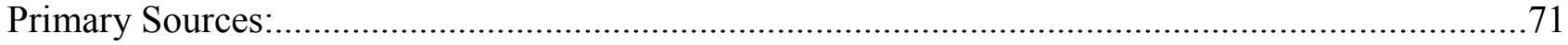

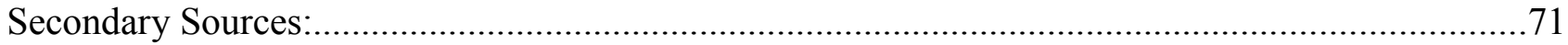




\section{Introduction}

Although warfare is rarely associated with women, they have always been a part of it. Either as nurses, reporters, suppliers, laundresses, telephone and radio operators, industrial laborers, chauffeurs or actual fighters, in one or another role, women have engaged in modern warfare. ${ }^{1}$ The Second World War provides many examples of these roles, yet women remained unrecognized when the war ended. The contribution of the Soviet women in the Second World War is immense yet often overlooked. They constituted $100 \%$ of nursing units, they replaced men in labor, maintained households, sent their fathers, husbands, children to the front, as well as took arms and defended their homeland on equal terms with men. ${ }^{2}$

This paper explores the unwillingness of the Soviet state to recognize the contribution of Soviet women combatants in the warfare of the Second World War. It proves that it was not the female's contribution to the warfare that was insignificant, but more an attempt of the Soviet state to portray it as such. The paper begins with a background information on the women's contribution to the war and home fronts. Later on it analyzes the tools of the Soviet state with the help of which Stalin chose to glorify some people while ignoring others. It answers the following questions: Why did Stalin feel the need to create fictional characters instead of recognizing the existing true heroes? Why were some heroes better than others? The paper argues that because of Stalin's attempt to portrait the Great Victory in the Great Patriotic

1 Yulia Ivanova, Khrabrejshie iz Prekrasnykh: Zhenschiny Rossii v Voinakh (Moskva: ROSSPEN, 2002), 256. Russian women in warfare - Crimean War - approx. 200; Russo-Turkish War - approx. 1500; RussoJapanese War - approx. 3000; World War One - approx. 25000; Civil War - approx. 60000; World War Two 800000.

2 John Erickson, "Soviet Women at War" in World Congress for Soviet and East European Studies, John Gordon Garrard, Carol Garrard, and Stephen White. World War 2 and the Soviet People. (New York: St. Martin's Press, 1993), 61. 
War as a collective one, he was very careful in selecting his heroes (mostly the best hero for Stalin was dead). In order to fully realize the extent to which the experiences of Soviet women were ignored, this research also conducts a comparative analysis of the post-war treatment of the Soviet male combatants. This thesis argues, that the post-war situation of male combatants did not differ that much from female's situation. It is true that the front line experiences of Soviet women in the Second World War have been discussed and researched much less in comparison to the scholarly work done about male participation in the same war. However, since percentage vise Soviet men were clearly leading in numbers on the front lines, they also got more, but still not that much, representation in postwar literature and discussions. These developments can be, first of all, explained through the prism of the Soviet regime in which individual memory was much less important than collective memory. Apart from the leaders of the Communist Party of Soviet Union and other few exceptions, there was no discussion in the Soviet Union about individual people and their particular deeds. Secondly, Stalin saw a possible threat to the regime coming from the demobilized soldiers. He was thus reluctant to encourage the establishment of veterans organizations and refused to recognize veterans as a separate social group. One of the main conclusions of the paper is that because of Stalin's fear of reforms and a tendency to portray each achievement of Soviet individuals as a collective one, both female and male combatants suffered a common fate of remaining in the shadow of the myth of the Great Patriotic War, according to which the Second World War was won collectively under a careful supervision of the country's first hero - Joseph Stalin. The paper ends with a discussion on the significance of gender in the context of military conflict. It demonstrates the importance of this issue with contemporary examples and proves that in the 
same way women's rights and war-time experiences were neglected after the end of the Second World War, in the same way they are also marginalized in contemporary conflicts all over the world.

There is a growing amount of historiography about the experiences of women combatants from 1939 to $1945 .{ }^{3}$ One can read about the participation of Irish, British, German, French or American women in the war, however there is much less scholarship existing on the contribution to the Second World War of the Soviet women. ${ }^{4}$ The research of war-time as well as post-war experiences of Soviet women combatants remains minimal. As Roger Markwick rightly underlines there is almost nothing written on the post-war destinies of women veterans. ${ }^{5}$ The first scholarly works on the topic of women combatants were published only in 1970s. One of them - "Sovetskie Zhenshchiny v Velikoŭ Otechestvennoü Voüne” (Soviet Women in the Great Patriotic War) by Murmantseva appeared in 1974. This book was about experiences of Soviet women during the war; yet it did not directly address womens front line experiences, rather it reviewed the lives of women during the war in general. For the most part, it was a quantitative analysis of statistics that underlined the immense contribution of women to the war on all fronts. Murmantseva herself called that contribution priceless. However, the book used a limited amount of primary sources and none of them expressed

3 Among many see - Karen Hagemann and Stefanie Schüler- Springorum. Home Front: the Military, War, and Gender in Twentieth-Century Germany (Oxford: Berg.; Williams, Mari A. 2002) A Forgotten Army: the Female Munitions Workers of South Wales, 1939-1945 (Cardiff: University of Wales Press.; Diamond, Hanna. 1999) Women and the Second World War in France, 1939-48: Choices and Constraints. (London [etc.]: Longman.; Muldowney, Mary. 2007) The Second World War and Irish Women: an Oral History. (Dublin: Irish Academic Press.; DOUIE, Vera. 1949) Daughters of Britain. (An Account of the Work of British Women During the Second World War.).

4 Ellen Jones Red Army and Society (Boston: Allen and Unwin, 1985), 101; Roger Markwick, D. "A Sacred Duty: Red Army Women Veterans Remembering the Great Fatherland War, 1941-1945," Australian Journal of Politics \& History (2008) 54 (3): 403-420.

5 Markwick, 418. 
strong opposition to the official version of the Soviet state. The importance of Murmantseva's work is that it was one of the first books that addressed women's war-time experiences separately from men's. It introduced the topic of gender into the historiography of Great Patriotic War.

It is worth noticing, that the Soviet/Russian approach towards women combatants of the Second World War has not changed much since 1970. The book by Ivanova "Khrabrejshie iz Prekrasnykh: Zhenschiny Rossii v Voinakh"(The Most Courageous Out of the Beautiful: Women of Russia in Wars) published in 2002 is a good proof of that. In regard of positive developments, Ivanova acknowledges the number of women that participated in the Great Patriotic War and that number coincided with the Western one, however it almost seems like the entire narrative of the book was written under Stalin's rule. It is full of loud slogans, over exaggerated patriotism and a complete lack of a discussion about the problems women encountered at the front. ${ }^{6}$ Such historiography demonstrates the enormous gap in the knowledge of the true experiences of Soviet women on the front lines of the Second World War.

Relying on numerous testimonies of Soviet women combatants, this thesis demonstrates the war and post-war realities of Soviet women soldiers. Main primary sources include interviews and correspondence collected by Belorussian journalist Svetlana Aleksievich in the book "War's Unwomanly Face" and a set of interviews of Soviet Army Air Force women veterans, conducted by a former American woman pilot Anne Noggle in " $A$ Dance with Death". Both of these books tell firsthand war and post-war experiences of Soviet

6 Ivanova, 173. Slogans such as "Russia was, is, and will be!" 
women veterans. However in the process of analyzing such primary sources, it is important to understand that individual memory is selective, and it is therefore hard to judge or determine women's honesty and openness in their interviews. At the same time, it is probably as close to the truth as one can ever get. "War's Unwomanly Face” was published in the 1980s, and still in fear of Soviet power, women might have been afraid to talk about all kinds of difficulties they encountered. Aleksievich acknowledged the problem of sincerity while interviewing women; she noticed that the greater the number of people in the room, the more official and "newspaper-like" were the stories of the women. ${ }^{7}$ If it was a one-on-one interview, then the story flowed more naturally, and a woman would address Aleksievich as she would a daughter. Additional interviewing problems included - old age, bad memory, and the heavy influence of patriotic myths. ${ }^{8}$ Noggle's book came out in 1990s, when the threat of Soviet persecution was theoretically gone, but it is hard to tell whether that made women less reluctant to speak out. "Wings, Women, and War: Soviet Airwomen in World War II Combat" by Reina Pennington complements Noggle's research about Soviet women pilots.

In regard to secondary sources, the paper heavily relies on Mark Edele's "Soviet Veterans of the Second World War: A Popular Movement in an Authoritarian Society 19411991", which is considered to be pioneering research on the post-war difficulties of Soviet veterans to be recognized as a single social group. Nina Tumarkin's "The Living \& The Dead: The Rise and Fall of The Cult of World War II in Russia," contributed to the discussion of the myth of Great Patriotic War and its commemoration. "Ivan's war: Life and Death in the Red Army, 1939-1945" by Catherine Merridale continues the topic of the Great Patriotic War's 7 Svetlana Aleksievich, U voüny ne zhenskoe litso ; Poslednie svideteli (Moskva: Ostozhe, 1998), 105.

8 Catherine Merridale, Ivan's War: Life and Death in the Red Army 1939-1945 (New York: Metropolitan Books Henry Holt and Company, 2006), 9. 
myth and introduces a general image of a Red Army rifleman Ivan. In The Comprehensive Guide to Soviet Orders and Medals medal collectors Paul McDaniel and Paul Schmitt name, demonstrate in pictures and explain the meanings of all orders and medals awarded by the Soviet Union. The majority of secondary sources approach the topic of Soviet veterans from the general perspective, and pinpoint the differences between the gender experiences only on the surface. Such an approach underlines once again, the wide-spread neglect of women's war and post-war experiences. Upon glancing at the historiographies of other countries, it becomes clear that avoiding the topic of women soldiers is not uncommon. In countries like Yugoslavia, Israel, Vietnam and to some extent also Germany and Britain, women shared the destiny of becoming the invisible combatants of World War Two. In general, war is not perceived as a feminine activity, therefore when historians write about wars they tend to omit the part about women combatants. As a result, history has airbrushed the contribution of women combatants to the best known and the most studied war of all times. ${ }^{9}$

This paper combines the existing historiography on the participation of the Soviet women in the Second World War with an analysis of the impact of Soviet propaganda on the creation of an image of the ideal Soviet woman. It proves that only war-time propaganda urged women to fight at the front. As soon as the war ended the majority of women were demobilized against their will and discouraged to pursue a military career. A more image of a woman as a mother and a housewife was emphasized yet again. According to the present historiography, it is evident that the main reasons for women's marginalization in the Soviet society include: gender ideology of the Soviet state and marginal status of women within it;

9 Campbell, 323. 
pro natalist policies of the Soviet state in which a woman was first of all a mother and a keeper of a household; and the psychological effects of war on former women combatants. As a consequence of all of these factors, the chapter on Soviet women soldiers, for a long time, remained a blank spot in the scholarship on the Great Patriotic War. Due to the constantly diminishing number of veterans of the Second World War and limited research that was done on the topic during the existence of the Soviet Union, the author of this thesis concludes that the story of the Soviet women combatants will never be researched to its full potential.

\section{Research Questions:}

What was the role of the Soviet propaganda in neglecting women's role as a soldier in the immediate post World War Two Soviet society?

Why did Soviet women combatants become a blank spot in the collective memory of World War Two?

Was gender the only reason why the experiences of Soviet women combatants were neglected? When compared to female's veterans what was the treatment of male veterans in the post-war Soviet society? 


\section{Background}

The only women's contribution to the warfare that the Soviet state was eager to recognize and promote was that to the labor front. Some women worked on a voluntary basis, whereas others were forced to work. Labor laws were tightened and there were cases when women were put before military tribunals for "absenteeism." ${ }^{10}$ If in 1940 38,4\% of women were contributing to national economy, then in 1945 it was already 55,3\%. ${ }^{11}$ The numbers of women increased in all spheres of economy - skilled workers, light and heavy industries (by $194038 \%$ of all industrial workers in the USSR were women ${ }^{12}$ ), transportation, agriculture, politics, blue-collar occupations, etc. ${ }^{13}$ As a result by 1945 out of a workforce of 11, 430, 900, Soviet women constituted 8, 661, 200. ${ }^{14}$ If in 1940 there were only 4\% if women working as tractor drivers, in 1944 that number skyrocketed to $81 \% .{ }^{15}$ Apart from filling spots in the labor market women were also donating blood to the front $-90 \%$ of all Soviet donors were women. ${ }^{16}$ During the war women took up male professions for the first time (train conductor), and the state was eager to honor them for that. At the same time, the labor front was not the only field where women had replaced men. They also fought side by side with men on the military front lines. The contribution of women to the labor front was indeed remarkable and worthy of recognition, but does that mean that their contribution to the front lines was less worthy?

In the "Women for Defense," published in 1942, Margaret Banning, relying on

10 Erickson, 55.

11 Svetlana Murmantseva, Sovetskie Zhenshchiny v Velikoŭ Otechestvennoŭ Voinne, (Moskva: Mysl', 1974), 26.

12 Gail Lapidus, Women in Soviet Society: Equality, Development, and Social Change (Berkeley: University of California Press, 1978), 172.

13 Murmantseva, Sovetskie Zhenshchiny v Velikoŭ Otechestvennoŭ Voŭne, 11-14.

14 Murmantseva, Sovetskie Zhenshchiny v Velikoŭ Otechestvennoĭ Voŭne, 36.

15 Erickson, 55.

16 Murmantseva, Sovetskie Zhenshchiny v Velikoŭ Otechestvennoŭ Voĭne, 108. 
"informed people," estimated the contribution of Soviet Women to the warfare of Second World War as insignificant. ${ }^{17}$ It is unclear which sources the author used in order to come up with her conclusions. And it seems that 1942 was too early to express such opinions, especially considering the fact, that the amount of mobilized women increased greatly between 1942 and 1945. Today's historiography would strongly disagree with Banning. John Erickson, for example, states that many women turned out to be the finest soldiers of the Red Army. ${ }^{18}$ The same opinion is expressed by the people who had shared duties with women combatants, such as a general of aviation Lavrienkov, who confirmed that men and women fought on the same terms and there was never a special clemency awarded to women. ${ }^{19}$ Personal accounts like those of Senior Lieutenant Serafima Amosova - Taranenko provide additional support: "...there were two regiments, one female and one male. We had the same missions, the same aircraft, and the same targets. The female regiment performed better and made more combat flights." ${ }^{20}$

The lack of research and information about the front line experiences of Soviet women in the Great Patriotic War does not change the fact that almost one million of them took an active part in defeating the enemy; some as Red Army soldiers and Air Force, others as members of partisan units. ${ }^{21}$ At the peak point, in 1943, women constituted $8 \%$ of the Soviet

17 Margaret Banning Culkin, Women For Defense (New York: Duell, Sloan and Pearce, 1942), 208.

18 Erickson, 59.

19 V. Lavrinenkov, Vozvrashchenie v Nebo, 2nd ed. (Moskva: Voenizdat, 1983), 56-7.

20 Anne Noggle, A Dance with Death: Soviet Airwomen in World War II (College Station: Texas A \& M University Press, 1994), 46.

21 S. Murantseva, Zhenshchiny v soldatskikh shineliakh (Moscow: 1971); K.J. Cottam, "Soviet Women Combat during World War Two: The Rear Services, Partisans, and Political Workers," Soviet Armed Forces Review Annual, (1981) vol. 5; J. Erickson, "Soviet Women at War," World War II and the Soviet People: Selected Papers from the Fourth World Congress for Soviet and East European Studies, Harrogate 1990. New York, 1993,; R. Pennington, "Offensive Women: Women in Combat in the Red Army," Time to Kill: The Soldier's Experience of War in the West, 1939-1945, ed. P. Addison and A. Calder. London 1997. 
armed forces. ${ }^{22}$ Due to the policies of the Soviet Union, it is hard, today, to research that topic and support it with hard evidence. During the war it was illegal to keep a diary. ${ }^{23}$ Public remembrance of war was banned. ${ }^{24}$ Many of Stalin's orders, such as Order no. 270, signed on 16 August 1941, that officially declared all Soviet POW's as "traitors to the motherland", and Order 227 "Not a Step Back" that prohibited retreat from the army, meaning that if a soldier surrendered he was a traitor, but if he retreated then he was a deserter, were only published in $1988 .^{25}$ Stalin forbade veterans to publish memoirs and there was no organization they could join in order to associate, share experiences and have a legal influence on the state's decision making. ${ }^{26}$ In a belief that war stories would distract people from contemporary problems, official literary critics tried to discourage editors and writers to publish anything about the war and instead write about something else. It was only during the time of the Thaw that Soviet readers first encountered war memoirs. ${ }^{27}$ After Brezhnev came to power, however, censorship rules were reintroduced. Memoirs were allowed to be published, but without mentioning the devastating defeats of 1941 nor the reasons behind these defeats; all of the memoirs were censored by the Military Publishing House. ${ }^{28}$ Writers were told to write only about the positive aspects of Soviet life during the war years. ${ }^{29}$

As a result of such policies, war time stories became a part of oral history, something that generations shared with their children and grandchildren. Since the war experiences were

22 Susanne Conze and Beate Fieseler, Soviet Women as Comrades-in-Arms: A Blind Spot in the History of the War (Urbana: University of Illinois Press, 2000), 212.

23 Merridale, 8.

24 Merridale, 362 .

25 John Garrard, World War Two and the Soviet People (New York: St. Martin's Press, 1993), 10-20; Tumarkin, 103.

26 For more details on publishing memoirs in post-war society see Tumarkin, 104.

27 Garrard, 32.

28 Garrard, 33-34.

29 Dunham, xxi. 
very painful, many veterans decided to keep their stories to themselves in order to protect their children. Due to higher mortality rate and fewer numbers in the army, there were not many women with direct front line experiences left by the time Soviet Union collapsed and veterans felt more free to speak out. That complicates the conduct of research devoted entirely to the experiences of Soviet women on the front lines. It is important to understand that there was no freedom of speech in the Soviet Union, veterans were oppressed by the state, and many of them, especially prisoners of war (POW), were incarcerated or sent to labor camps. Everything that happened in the Soviet Union was strictly controlled by Kremlin. There were many tools in the hands of the state - widespread propaganda, control over each aspect of people's everyday lives, various awards and privileges. Stalin created the whole myth about the Great Patriotic War, that is how World War Two was known among Soviets, and with the help of that myth he was able to manipulate Soviet society into believing what he wanted them to believe. ${ }^{30}$

30 Napoleonic war of 1812 was known as the Patriotic War, a Russian victory against another Western invader. 


\section{Tools of State Manipulation}

\section{Control over Press and Education}

The Great Patriotic War was, according to the official state line, a people's war, and it was won by a collective effort of all of its citizens. The whole postwar narrative of Soviet Union concentrated on Stalin's role as a "War-Hero-in-Chief." ${ }^{31}$ The myth of the Great Patriotic War highly depended on the presentation of heroes and heroines created by the state. However the number of these heroes was very limited, because the main goal of Stalin was to shape the collective view of the events of war. ${ }^{32}$ Instead of individual people, entire cities were given the status of "Hero-cities" (gorod geroi). There is a considerable amount of literature describing the heroic deeds of Soviet women during the war, but the majority of these books, published between 1941 and 1992, are of questionable content and interpretation. After the end of the war Stalin forbade veterans to publish any kinds of war memoirs. After 1947, according to the peacetime directive, all novels published in the USSR had to describe "the new Soviet man in the struggle for reconstruction of the socialist fatherland." ${ }^{33}$ That meant no books were published about the war at all. Stalin created a myth of the Great Patriotic War and made sure that everything and everyone acted within the frames of that myth. He also took care that a younger generation would learn the correct history. In 1946 he introduced new directives for teaching history, which stated that history should "assist the state to educate youth in the right way." 34

31 Mark Edele Soviet Veterans of the Second World War: A Popular Movement in an Authoritarian Society 19411991 (Oxford, New York: Oxford University Press, 2008), 7.

32 Culture and Entertainment in Wartime Russia, ed. by Richard Stites (Bloomington: Indiana Univ. Press, 1995), 179.

33 Michel Gordey, Visa to Moscow (New York: Alfred A.Knopf, 1952), 203.

34 Gordey, 236. 
The ,right way“ to teach about the Great Patriotic War was:

to show that the entire world realizes at the present time, and will realize through future centuries, that the Soviet people, by its heroic struggle, saved European civilization from cataclysm, from death (...) the USSR had to fight the entire Hitler coalition all by itself, for three years out of four. The heroism of the men of the Soviets constitutes an absolutely new degree of heroism, which is not within the reach of the men of bourgeois society... ${ }^{35}$

During Stalin times, there were still some movies, newspaper articles as well as books published on the topic of Great Patriotic War, but all of them followed the state agenda, thus depicting only those stories that went along with the official line from the Kremlin. During the disastrous defeats of the Red Army in 1941, Stalin's name rarely appeared in press, however as John Barber notices in the "Image of Stalin in Soviet Propaganda," after the first successes in Stalingrad, each new victory was assigned to Stalin. He was the "genius organizer of our victories" and the "great captain of the Soviet people." 36 The Soviet society was constantly reminded of that by the numerous monuments, posters and photographs of Stalin that could be found all over the Soviet Union. The Red Army Museum, for instance, had an image or a quotation of Stalin on each of its walls. ${ }^{37}$ It seemed like the name of Stalin could be attached to anything: Red Army pilots were "Stalinist falcons"; Red Army infantrymen fought with "Stalinist rifles", and cavalrymen with "Stalinist sabres"; people were inspired by the "Stalinist spirit" and the children of the Soviet Union were "Stalinist youth." Stalin was the National Hero No. $1 .^{38}$

35 Gordey, 247-248.

36 Garrard, 42-43

37 Gordey, 185.

38 Edgar Snow, The pattern of Soviet power (New York: Random House, 1945), 78. 


\section{Hero of the Soviet Union}

One way to read the official Soviet line is by analyzing the awards and honors given in the USSR. What kinds of people were honored by the state and why? There were numerous awards in the Soviet Union; this study will closely look at the main one - Hero of the Soviet Union (hereafter cited as HSU). HSU was the highest award of distinction given in the Soviet Union. Before 1947 all Soviet medals and orders ensured certain privileges. After 1947 apart from the order itself and a certificate that accompanied it, the awards did not imply any financial support or social privileges (with exception of HSU, Heroes of Socialist Labor and Cavaliers of the Order of Glory). ${ }^{39}$ Initially, HSU was supposed to bring prestige to its beholder, therefore receiving an award like that was a dream of many. However, in the postwar era the attitude towards the award changed and veterans laughed at the younger generation who was ready to sacrifice all in order to receive a HSU. Young people thought HSU meant fame and honor, whereas veterans, who experienced the collective neglect in the post-war period, had thrown away their medals a long time before ${ }^{40}$ During the period from 1934 to 1991, 12745 people received HSU. Out of this number, 11635 people received HSU for their services in the Great Patriotic War. HSU was "conferred for personal or collective efforts involving a heroic feat for the Soviet State and Society. ${ }^{, 41}$ In that way, theoretically HSU was given to anyone, regardless of gender, who proved him/herself with a courageous heroic deed. In practice however, only 90 women ever received the HSU, which accounts for less than $1 \%$ of all awarded. Apart from that, it was possible to receive the HSU twice (141), three times (3)

$39 \mathrm{McDaniel}$ and Schmitt, 11.

40 Pirogov, 283.

41 Paul McDaniel and Paul Schmitt, The Comprehensive Guide to Soviet Orders and Medals (Arlington: Historical Research, 1997), 22. 
or even four times (Marshal Zhukov and Leonid Brezhnev). Women, however, never received the HSU twice. ${ }^{42}$

Maybe such statistics are fair and indeed not as many women "deserved" the HSU, but more likely that the Soviet State was simply reluctant to give its highest award to women. The commander of $586^{\text {th }}$ regiment Gridnev explained why none of the women under his command received the HSU:"Not one woman pilot was awarded Hero of the Soviet Union in our regiment, on account of the prejudice and foolishness of the commander of Fighter Aviation of PVO, General Ossipenko. He hated women's $586^{\text {th }}$ regiment and its commander." ${ }^{43}$ This quote demonstrates military hostility to women and traditional gender discrimination. A process of receiving HSU included an individual recommendation from a regiment commander. Senior commanders viewed recommendations made by a male commander for a female subordinate with suspicion of a "special relationship" between the two. ${ }^{44}$ In order to avoid being suspected of having an affair, male commanders were reluctant to nominate women for HSU. It is possible to assume that more women would get HSU, but since the award was not given to people who were considered missing in action, that was not the case. Such was the case of Ekaterina Zelenko, who was one of the last recipients of HSU in 1990. Zelenko, a deputy squadron commander of $135^{\text {th }}$ Bomber Aviation Regiment, was a candidate for HSU since 1941. Since she was considered "missing in action", Zelenko could not receive the award. It was only in 1991 when enough documentation and proof was collected in order to prove that

42 McDaniel and Schmitt, 20-25.

43 Reina Pennington and John Erickson, Wings, women, and war: Soviet airwomen in World War II combat (Lawrence: University Press of Kansas, 2001), 124.

44 Kazimiera Cottam Women in War and Resistance: Selected Biographies of Soviet Women Soldiers (Nepean: New Military Publishing, 1998), xxiv. 
Zelenko perished in combat that she received HSU posthumously. ${ }^{45}$

It was as easy for Stalin to create a hero as to destroy one. Thus it was not enough to receive HSU, one had to either die or live up to the expectations of the award for the rest of his/her life. Anna Timofeyeva-Yegorova, deputy commander of $805^{\text {th }}$ Ground Attack Regiment, was granted HSU posthumously in 1944, however when it turned out that the woman was not only alive, but she had become a POW, the award was withdrawn. It was only in 1965 when Yegorova received her HSU. ${ }^{46}$ Stalin was much more eager to honor HSU posthumously; for him the best hero was a dead one. ${ }^{47}$ In case of women recipients, more than $50 \%$ (47 out of 90$)$ were awarded posthumously. ${ }^{48}$

A strong case of Stalin's power over the historical legacies is presented in Price of Victory written by Boris Sokolov. In his book, the author draws an interesting parallel of Stalin's regime with Orwell's "1984," where Winston edited newspapers from the past in order to erase the names of people, who used to be heroes, but due to certain misdeeds, became undesirable for the state. Most of the "erased" questioned the regime of the "Big Brother" and tried to go against it. In a similar manner, names of people disappeared from the pages of the Soviet press. Sokolov tells a story of Petr Tavrin, who in 1943 received the HSU for courage and heroism. In 1944 Tavrin was disclosed as a German spy. Obviously, one could not be a German spy and a Hero of the Soviet Union at the same time. Thus all of the press archives in Soviet libraries regarding the order from seventeenth of October 1943, which granted Tavrin the HSU, were edited. The surname Tavrin was replaced with the one of an unknown person

45 Pennington and Erickson, 129.

46 Noggle, 228.

47 Tumarkin, 80 .

48 Ivanova, 247-254. 
Stepan Susaev. A similar occurrence happened to Beria, whose name, upon his arrest in 1953 was erased from Soviet encyclopedias, and General Zhukov. ${ }^{49}$ Zhukov a war general credited with the final defeat of Germany, yet after the end of Great Patriotic War Stalin saw a serious threat in Zhukov. As the result the general was stripped of his position as a Military Governor and was sent away from Moscow to Odessa. It was only after the death of Stalin in 1953 that Zhukov returned to Moscow.

In such a way, purely for propaganda reasons, Stalin chose to highlight certain deeds of certain individuals, in order to raise the patriotism and morale of the Soviet population. He created a set of heroes who would motivate the population to fight and die for their country. People like Zoja Kosmodejanskaja, pilot Maria Raskova or General Zhukov appeared in the headlines of newspapers more often than others, they received HSU, and were proclaimed state-wide heroes. However, the recognition that existed in the Soviet Union was very limited: "Who and what should be remembered was decided by Stalin and then by the party with a ruthless principle of selection. Whatever enhanced their reputation was mythologized and what did not jibe with their version of the Great Patriotic War was simply not printed." ${ }^{50}$ As soon as someone presented a threat, Stalin eliminated them; he was the "Big Brother" of the Soviet Union. As Sartorti underlines in "On the Making of Heroes, Heroines, \& Saints," there were only about 10000 official heroes glorified by the Soviet state. Out of estimated twenty to twenty eight million of military and civilian losses that number constitutes less that $0.1 \%$ of the dead. ${ }^{51}$ So what was making some people more worthy of others for becoming a hero?

49 Boris Sokolov, Cena Pobedy: Velikaja Otečestvennaja: Neizvestnoe ob Izvestnom (Moskva: Moskovskij Rabočij, 1991), 130-131.

50 Garrard, 6.

51 Stites, 176; Zubkova, 20. 
According to Sartorti, there were a couple of requirements which made some people more "heroic" than others. Among them were technical mastery and superhuman strength, or exceptional personal qualities, or gifts of nature such as charm, beauty and sex appeal. ${ }^{52}$

\section{Myth of Zoia}

The story of a Soviet partisan Zoia Kosmodem'ianskaia is undeniably the most famous example of the how Soviet state created myths and tried to motivate people to fight till the last breath. The official story about Zoia depicted her as a partisan, who planned to set on fire the stables in the village where Germans lodged. That mission of hers failed, Zoia was captured, tortured and eventually hung by the Germans. There were movies and songs composed about Zoia; monuments were erected in her honor; posthumously she received the HSU and became an inspiration of thousands of girls all over the Soviet Union.

The myth of Zoia collapsed together with the Soviet Union. Some say there was no Zoia at all, others insist that she was not hanged, but stoned to death. More evidence suggested that there were no Germans in the village, where Zoia was supposedly tortured. Witnesses confess that Zoia was not punished alone and the same fate awaited her partner Vera Voloshina (who has never been mentioned in the official storyline). More accounts suggested that Zoia suffered from schizophrenia. ${ }^{53}$ The exact truth will probably never be known. So why did Stalin feel the need to compose stories and create heroines, instead of praising the real life stories of hundreds of thousands of women fighting at the front? For Stalin there was one thing that was good about Zoia - she was dead. That meant that she could not have returned and

52 Stites, 182.

53 Stites, 182-190. 
shared her actual war-time experiences. She could not have questioned the official state line, she could not have summoned people into groups that would rebel against or demand more rights from Stalin. Additionally to that Stalin could create any myths around the character of Zoia, since he knew that she would not be able to come back and contradict any of it. No matter the sex, for Stalin the best hero was always dead, because a dead hero sacrificed to the country the most valuable thing in his/her possession - life. ${ }^{54}$

One more example of the collapsed myths is that of Vlasovites - men who instead of being sent to German camps agreed to fight the Soviet Union on the side of Germany. Back in 1945 they were sent for execution and incarceration, whereas today in some parts of Russia, Vlasovites are considered to be heroes..$^{55}$

Even though Snow argues that all of the millions of Soviet people who supported Stalin were the least sophisticated, it is crucial to understand how skilfully Stalin used all of the tools he had at his hands. ${ }^{56}$ Interviews conducted by Noggle in 1990s indicate the power of the Stalinist state machine. Only one woman out of 69, Sergeant Antonina Khokhlova Dubkova, admitted that she detested Stalin - "I hated Stalin throughout my life, beginning with the murder of Kirov...and I hated Stalin when the war started. Why should I fight for Stalin? He's a man - let him fight for himself!" ${ }^{57}$ All the others remained loyal to Stalin (more to Homeland) as they spoke. Major Marta Meriuts recollects the story: “...after the war, there was a reception in the Kremlin...the girls from the regiment were invited. The commander of the front, under whom we fought during the war, asked us why we had been asked to this

54 Tumarkin, 80 .

55 Stites, 204.

56 Snow, 147.

57 Noggle, 117 
reception and who we were." ${ }^{58}$ Meriuts narrates this story without expressing any kind of objection, like there is nothing special about a commander who had no idea that he was in charge of a female regiment. In the Soviet state there was only one person who stood above everyone else - Joseph Vissarionovich Stalin.

58 Noggle, 137 


\section{Why not to Recognize Women as Soldiers?}

According to Pennington in "Wings, Women, and War: Soviet Airwomen in World War II Combat", there are three reasons why the front line experiences of Soviet women combatants were neglected: ideology on gender roles, pro-natalist policies of the state and the psychological effects of the war. ${ }^{59}$ The following chapter aims at discussing these reasons in more depth, relying on existing secondary as well as primary sources.

\section{Soviet gender ideology}

According to the principles of socialism, gender discrimination should not exist. Therefore in Soviet Union - the best representative example of socialism - men and women were supposedly equal; the October Revolution of 1917, has officially proclaimed them as such. The Soviet Union was also the first major country to grant women full citizenship and legal equality. ${ }^{60}$ As it often happens, reality differs from theory. The Stalinist state insisted on very distinct gender roles. Post revolutionary changes mainly referred to the labor policy, that encouraged women to enter the labor market in order to help restore the state after the First World War. Apart from that, the worlds of men and women were clearly separated and gendered - men were combatants, protectors and leaders, whereas women were mothers and keepers of the household. When future Junior Lieutenant Raisa Zhitova Yushina asked her mom, if she would ever fly, her mother's answer was, "Yes, from the stove to the floor!"'61

59 Pennington and Erickson, 143-160.

60 Pennington and Erickson, 6.

61 Noggle, 87. 


\section{Soviet Airwomen}

It appears that Stalin was almost forced to allow some women to pursue military careers in order to confirm the ideals of the gender equality of the October Revolution. When in 1938 Maria Raskova, Polina Osipenko and Valentina Grizodubova set goals for a record setting long-distance flight of the Rodina (long distance flight from Moscow to Komsomolsk that covered $6500 \mathrm{~km}$ ), the press spotlighted this event from A to Z. As the result of such a large press coverage these three women became widely known figures and, as testimonies in Noggle's book prove, thousands of girls all over the Soviet Union were worshiping Raskova. As Pennington explains, such tolerance of Soviet leadership for female aviators served several interests at the same time. First of all, the Soviet Union could demonstrate the latest military capabilities, and secondly it introduced the image of a "new Soviet woman."62 It was a woman that was equal to a man, capable of reaching higher grounds, a woman for whom nothing was impossible in a socialist state.

Despite the fact that Rodina flight was not an entire success and the women were forced to make an emergency landing, all three of them received the HSU. Raskova, Osipenko and Grizodubova were the first women ever to receive the highest award of Soviet Union. They were also the only women awarded the HSU before World War Two. What impact did the imperfection of the Rodina flight have on the image of the Soviet woman? From one point of view the three women still broke the records for international women's straight-line distance and nonstop broken line distance flights. ${ }^{63}$ However, from the other point of view they made a forced landing with a huge rescue campaign, hence to some extent they failed. Such an 
outcome gave Stalin a possibility to underline once more that women, no matter how hard they try, will never succeed as well as men in military occupations.

\section{Femininity and Diminutiveness}

In the same manner as there are no feminine equivalents for professor, doctor or soldier in English language, because those were initially pure masculine professions, there are also no feminine equivalents in Russian for a tankist (tanker), pekhotinec (infantryman) or avtomatchik (submachine gunner). War was simply not a job for women, therefore in those rare cases, when women were mentioned as fighters, there was always some diminutive aspect to it. As Pennington describes it, when men were called falcons and eagles, women were eaglets and "girl-pilots". Even though both men and women who fought in the war were of a very young age, men were never referred to as "boy-pilots". Interestingly enough, according to the Soviet air combat tactics, men were responsible for attacking, while women in the roles of wingmen protected men. ${ }^{64}$ Thus women were actually protectors. The depiction of men as heroes was based on their actions, whereas women were heroines due to their virtues: patience, gentleness, faithfulness, i.e. spiritual qualities rather than particular deeds. The discussion of women actually killing someone was considered a taboo topic in war-time literature. In one of his poems, Boris Paliichuk underlined femininity in a sniper girl. ${ }^{65}$

64 Pennington and Erickson, 131-132.

65 Katharine Hodgson, "Soviet Women's Poetry of World War 2" World Congress for Soviet and East European Studies in World War 2 and the Soviet People ed. John Gordon Garrard, Carol Garrard, and Stephen White, (New York: St. Martin's Press, 1993), 82. 
...You can see a carefully darned stocking.

The mines crashed and rumbled,

But, true to her girlish habits,

In a cellar, by the oil-lamp,

She had sat and darned her stocking.

In such a manner instead of describing woman's professional skills, the author concentrates on her looks and underlines her femininity. Nevertheless, the job of a sniper, regardless of gender, is to kill. Nothing could change the fact that Soviet women snipers did kill Germans. As Roger Markwick found out from memoirs, women snipers often did not perceive Germans as human beings, were full of vengeance, hungry to kill more of them and never had any regrets. ${ }^{66}$ However, there was no space for a determined cruel woman killer like that in the Soviet society, therefore the topic was considered a taboo.

Even some of the military orders were written especially with a purpose to stress women's otherness from men. There were several orders from the Peoples Commissar of Defense that addresses solely women. Among them was a mandate that ensured monthly 200 grams of chocolate for non-smoking women. ${ }^{67}$ On the one hand, women got special treatment, but on the other hand provision of chocolate and candies can also be seen as a reference to their femininity. Smoking and drinking was considered to be specifically male pleasures enjoyed in pure masculine company. ${ }^{68}$ Caught smoking, Raskova said once, "When the war is over...- I will stop smoking. You're right, it's not the sort of thing for a woman to do, but after all we're all now occupied with something that is not women's business" ${ }^{69}$

66 Roger Markwick, 416.

67 Ivanova, 246

68 Lilya Kaganovsky How The Soviet State Was Unmade: Cultural Fantasy and Male Subjectivity Under Stalin (Pittsburgh: University of Pittsburgh Press, 2008), 106.

69 Pennington and Erickson, 122. 
Soviet propaganda contributed a lot to the creation of an image of a Soviet woman soldier. For the most part it was the only means of communication between the war and home fronts, hence the only source from which Soviet society could create their impression about women combatants. It was possible to find some articles about women combatants, but as Pennington noticed most of them were published in venues directed at female audiences (journals like Krestianka and Rabotnica). Those published in more widespread newspapers were usually connected to special events, like International Women's Day, which celebrated women collectively. ${ }^{70}$ For example, the reason why the 46 th women's regiment received the most coverage in press was, according to Pennington's beliefs, its vulnerability. This was the regiment that flew the most outdated wooden planes. ${ }^{71}$ Carefully selected photos from the front demonstrated women looking into the mirrors or sitting in the dug-out with plants, underlining their domestic nature, stressing the point that women will always remain women, their femininity makes them unsuitable for war. ${ }^{72}$ In their interviews women veterans admitted to curling their hair before flight in order to always look beautiful and of embroidering flowers on their cloths; but does remaining feminine on the front necessarily imply combat inferiority ${ }^{73}$ Did not men have their ways to relax and feel more comfortable during the war? Evidence suggests that male soldiers often found their remedy in the bottle. ${ }^{74}$ Beginning with mobilization and all throughout their service and demobilization, alcohol was an inevitable ingredient of the Soviet Army. ${ }^{75}$

70 Pennington and Erickson, 61.

71 Pennington and Erickson, 62.

72 Pennington and Erickson, 134.

73 Noggle, 28, 56.

74Pennington and Erickson, 169.

75 Viktor Suvorov. Inside the Soviet Army (New York: Macmillan Publishing CO., Incs, 1982), 217, 238, 259. 
The Soviet press was fast in reporting how women differed from men. It stressed women's femininity, unsuitability for warfare and eagerly published photos of women standing in front of an airplane with flowers drawn on them. Less often, if at all, did the press mention that women were living in the same conditions as men without separate hygienic utilities, and even without appropriately fitted uniforms for women. One veteran remembered the lack of soap and water, and how girls washed themselves with the water from the puddles. ${ }^{76}$ Private Smirnova remembered she had to walk in size 42 male footwear, instead of her own 34 and that their hygienic needs were almost never met. ${ }^{77}$

\section{The Labor Front}

Most of information about women combatants was overshadowed by the enormous amount of press dedicated to the other images of Soviet women. Images of women replacing men at work, nursing them, and women waiting for their men to come back from war. Such a role of a woman in Soviet society was distinct and well established. Thus those few front line stories that made it to press were not capable of changing traditional perceptions. The Soviet state actively promoted an image of women in industry. The popularity of an image of a woman worker is proven by the headlines of war-time articles, analyzed by Gregory Smith in his dissertation "The Impact of World War II on Women, Family Life, and Mores in Moscow, 1941-1945", where women were encouraged to work and fight, yet always behind their men. In the desperate times, when nearly all labor sectors lacked workers, newspapers declared "Women Can Do all that Men Can Do!" or "Young Women to the Machine Tools! To the

76 Noggle, 60.

77 Aleksievich, 78. 
Tractors! Wives and Sisters of Fighters, Go to Work to the Factories!" The media invited women to "Work for the Loved Ones at Front", and at the same time it pointed to the place of women - "Behind their Men!"78 War-time slogans also invited women to work - "Take the place of men, learn their trades, sacrifice all!'”n the one hand the state declared that women can do all that men can, but on the other hand it clearly implied that women should only do what state needs them to do. In those cases when women occupied themselves with "wrong activities", like becoming combatants, they got no recognition nor support from the state.

During Stalin's rule, in the post-war years, it was the First of May, The Labor Day, and not the Ninth of May, the Victory Day, that became the greatest holiday in the Soviet Union. ${ }^{79}$ From a following selection of holidays, one can clearly see that Stalin was prioritizing labor over the celebration of victory in the war. A great emphasis was put on the importance of labor. In the immediate post-war period, the country was in urgent need of labor power; the images of a male worker as well as of a female worker flourished in the post-war Soviet society. Similar patterns continued long after the death of Stalin. Even a medal for a Veteran of Labor was introduced two years before the medal for a Veteran of the Armed Forces of the USSR $^{80}$ All in all, at the end of the war, the only recognition women got was for their contribution to the labor front. In his speeches, Stalin thanked women for their contribution to the war, emphasizing all the work they accomplished on the home front as he ignored women combatants: “...For the sake of the honor and independence of the Motherland Soviet women,

\footnotetext{
78 Gregory Malloy Smith, 1989. "The Impact of World War II on Women, Family Life, and Mores in Moscow, 1941-1945" (PhD diss., Stanford University, 1989) - Caption of Vecherniaia Moskva July $5^{\text {th }} 1941$; caption of Komsomol'skaia Pravda July $3^{\text {rd }} 1941$; caption of Vecherniaia Moskva August $16^{\text {th }} 1941$

79 Gordey, 53.

80 McDaniel and Schmitt, 310-313. The medal for a Veteran of Labor was introduced on $29^{\text {th }}$ of April 1974, whereas the medal for a Veteran of the Armed Forces of the USSR on May $20^{\text {th }} 1976$.
} 
young men and girls are displaying true valor and heroism on the labor front. They have shown themselves worthy of their fathers and sons, husbands and brothers who are defending the Motherland against the German-fascist fiends..."

\section{War Is Not Women's Business}

The war mixed the roles of men and women in Soviet society. By occupying traditional male positions, women broke gender restrictions of the Soviet state. Stalin did not plan to use women as soldiers to such an extent, when the Second World War commenced. However, due to extreme human losses, he did not have much of a choice. Victory had to be achieved at all costs. According to John Erickson mass mobilization of women began in 1942 due to catastrophic shortage of manpower. In 1945 246, 530 women were mobilized, which accounted for $76.5 \%$ of all mobilized that year. ${ }^{82}$

Following the Soviet victory, Stalin was determined to resume traditional gender roles. The war was considered an exceptional force majeure situation, which demanded women to fight, but in no way was the perception of the women's place in the Soviet society changed. In Gendered Peace Donna Pankhurst states that in countries that aim to build a new society after a conflict, women have higher chances to gain more rights and recognition. ${ }^{83}$ Stalin clearly did not intend to build a new society, thus Soviet women did not get more recognition in the postwar Soviet society. Most of the women soldiers were almost instantly demobilized. Apart from that, from now on the state highly discouraged, if not forbade, them to continue a military

81 Speech at Celebration Meeting of the Moscow Soviet of Working People's Deputies and Moscow Party and Public Organizations by J. Stalin November $6^{\text {th }} 1944$

82 Erickson, 62

83 Donna Pankhurst, Gendered Peace: Women's Struggles for Post-war Justice and Reconciliation (New York: Routledge Taylor \& Francis Group, 2008), 14. 
career. ${ }^{84}$ Many women were not willing to retire, "And then it came to who should retire. It was not the men, of course; I was made to retire, and I didn't want to." ${ }^{\prime 85}$

Often health issues were used as an excuse to demobilize women. Ekaterina Ryabova was forced to retire due to her weak health, however the woman managed to graduate from college, travel around the world, give birth to a child and start graduate school within two years after the war. ${ }^{86}$ It is highly unlikely that a person with weak health would be able to accomplish all of these things in two years.

Not only were women sent home, but they were also encouraged to forget about their war-time experiences. One of the most famous quotes supporting this thought was expressed by the nominal Soviet head of state Kalinin in 1945:

Equality for women has existed in our country since the very first day of the October Revolution. But you have won equality for women in yet another sphere in the defense of your country: arms in hand. You have won equal rights for women in a fields in which they hitherto have not taken such a direct path. But allow me, as one grown wise with years, to say to you: do not give yourself airs in your future practical work. Do not talk of the services you rendered, let others do it for you. That will be better. ${ }^{87}$

The message of Kalinin's speech is clear: he thanked women for everything they have done, and encouraged them to forget it all and come back to normal life as soon as possible. It is interesting to note that in books published in the Soviet Union, such as by Murmantseva's "Sovetskie Zhenshchiny v Velikor̆ Otechestvennö̌ Vorne," the last three sentences of Kalinin's quote are omitted. It is clear that the analysis of the entire quote depends on those last 84 Reina Pennington "Do Not Speak of the Service You Rendered: Women Veterans of Aviation in the Soviet Union" The Journal of Slavic Military Studies, Vol. 9, No. 1, (London: Frank Cass, March 1996), 141. 85 Noggle, 184. 86 Pennington and Erickson, 159.

87 M. Kalinin, On Communist Education: Selected Speeches and Articles (Moscow: Foreign Languages Publishing House, 1953), 428. 
sentences. Western analysis, such as an article by Pennington "Do Not Speak of the Service You Rendered: Women Veterans of Aviation in the Soviet Union" criticizes Kalinin for neglecting women's experiences, whereas Soviet analysis (Murmantseva's book) concludes the quote by Kalinin - "The Homeland deservedly assessed heroic deeds of its courageous daughters by showering them with attention and care."${ }^{98}$

It is important to underline that women themselves acknowledged that participating in the war felt unnatural to them. It was not only the state, but also the people, that segregated the roles of two sexes. The collection of interviews of Soviet Air Force women in Noggle's book clearly demonstrates this. The majority of women interviewed, among them Major Marya Smirnova, Senior Sergeant Nina Karasyova-Buzina, the mother of Junior Lieutenant Raisa Zhitova-Yushina and Senior Lieutenant Alexandra Akimova all agreed that war was not an occupation for a female. ${ }^{89}$ Also men had an opinion about women's participation in the warfare - Lieutenant-Colonel Valentin Markov confesses feeling shocked upon finding out that he had been appointed to command a female regiment, “...I left the office angry and pale...the hair [of my friends] rose in surprise and indignation. They believed I would have to go through hell." His opinion changed later on, when he admitted that it was actually easier to command a female regiment. ${ }^{90}$ At the same time, some men said that the presence of women on the front enhanced their experiences, "You can not even imagine how beautiful is female's glance and laughter at war!"'91 There is also a proof that regiments which included at least a certain number of women were more disciplined. First of all many women taught young boys how to

88 Murmantseva, Sovetskie zhenshchiny v Velikoü Otechestvennő voine, 210.

89 Noggle, 37, 85, 87, 94, 124 .

90 Noggle, 103-105.

91 Aleksievich, 109. 
do laundry and sew patches on uniforms. Second, men took better care of themselves in order to appeal to the opposite sex. ${ }^{92}$ Many male veterans had great respect for women combatants, "Compared to her [wife] I did nothing for the victory, because I am a man I had to do it. Those girls, who went through the war should be worshiped by all veterans. ${ }^{993}$

Whether women wanted to fight or if it was a job for them or not, life and circumstances forced them to take arms. The statistics that Murmanteva provided in her book on women that showed increased percentages in labor, front lines, nursing, etc, created an impression that the Great Patriotic War was actually a woman's war. One of the strongest opinions on the topic was expressed by a Soviet feminist, "They say this is a men's war, but there has never in history been anything that was more of a woman's war. The men only have to fight, but we to feed the Army and clothe it and nurse it and arm it and protect the next generation all at once. No wonder we hate war more than men do!"94 Thus these women fully deserved to be recognized by the state they served and died for; their contribution to combat was all but insignificant.

\section{The need to increase Soviet population}

The order, signed on the first of September 1939 that permitted military skilled women to be a part of an army and navy, presupposes that Stalin was not totally against women's participation in the army. ${ }^{95}$ The same idea comes to mind if one thinks about his consent to form a purely female Air Force regiment lead by Maria Raskova. Thus Stalin did not reject the idea of a limited amount of women in the military. He was more concerned with the constantly

92 V. Mizin, Snăper Petrova (Leningrad: Lenizdat, 1988)

93 Aleksievich, 110.

94 Snow, 78.

95 Murmantseva, Sovetskie Zhenshchiny v Velikoŭ Otechestvennoŭ Voĭne, 119. 
increasing number of women in the army, as well as their growing ambitions. Many women wanted to continue their military careers also after the end of the war, whereas Stalin perceived women in the military as a temporary phenomena. After the end of the Second World War and an estimated loss of twenty million people, Stalin needed women to increase the Soviet population. ${ }^{96}$

Women's main role in life, according to Stalin, was to be a mother. He has always considered motherhood to be the main task of a woman. Starting from the mid 1930s he banned abortions, minimized the amount of birth control medicine, and made divorces extremely costly, therefore almost impossible. A possible military career would distract women from becoming mothers, and therefore Stalin did not encourage any further military careers. During the post-war years, the dominating image of a Soviet woman featured motherhood. Quick demobilization of women from the military, introduction of various motherhood awards, as well as new amendments to old laws demonstrate this abrupt shift. Both the title and the order of "Mother Heroine" were established in the summer of 1944. It was the highest recognition award given to women who have given birth to ten or more children. One more award was established in 1944 - the order of Maternal Glory - that was given to women with seven, eight and nine children. There were three classes of Maternal Glory, the more children a woman had the higher was the class of her award. ${ }^{97}$ Instead of gaining medals and recognition for military service, women received medals and state recognition for motherhood.

96 Susan Linz, "World War Two and Soviet Economic Growth", The Impact of WWII on the Soviet Union, ed. Susan Linz (Irvine: Rowman \& Allaheld, 1985), 207. 97 McDaniel and Schmitt, 364-374. 
The Soviet state subsidized childbearing before the war and continued to do so even more after it. Women received money for a baby's layette and monthly food allowances during the first year of an infant. Apart from that, women who had more than six children were entitled to a bonus of $\$ 400$ for five years and an additional bonus of $\$ 1000$ for each subsequent child. The more children a woman had the greater were the financial subsidies. In addition to money, women's pregnancy leave was prolonged, food rations of pregnant women were doubled and they received extra access to food and clothing. ${ }^{98}$ New laws also made sure that unmarried women with children would be properly subsidized, whereas childless people between the age of 20 to 50 were punished with an imposition of a special tax. ${ }^{99}$ In July 1944 Stalin introduced even stricter laws on divorces and new incentives to stimulate more marriages. From July 1944 common-law mothers and their children had no right to husband's benefits and estates. As a result, thousands of couples all over Soviet Union went to register as man and wife. A divorce became more expensive and was considered a permanent black mark on the record of a person, especially Party members. The main goal behind all these innovations in 1944 was for the Soviet Union to have the highest birth-rate in the world. ${ }^{100}$

Never before did Stalin need the Soviet population to increase as fast as after the end of the Second World War. War casualties were devastating, the state lost millions of people, the majority of whom were men. Apart from war deaths, at least ten million children who would have been born in peacetime, were not born due to the war. ${ }^{101}$ Women were pressured to start reproducing instantly. The state was in urgent need of men who would rebuild the Soviet state.

98 Snow, 18.

99 Smith, 278-279.

100Snow, 19-22.

101Linz, 207. 
But were women physically capable of having children after the years of such a destructive war, full of sieges, bombings, shortages, purges and misery?

A Baby. Really?

Even though very few women interviewed by Noggle complained about being incapable of having children, there are reasons to believe that many women veterans faced that problem. Daily lifting of 100 kilos of bombs manually must have had negative consequences for women's health. Senior mechanic Karasyova-Buzina convinced Noggle of her good health, "There was some question as to whether we mechanics could bear children after the heavy work and the overstraining of our strength during the war, but it didn't affect us. We were small and slim during the war, and we had bad nutrition, never enough sleep, and very hard work, but no one complained. I never even felt tired." ${ }^{\prime 102}$ The fact that none of the women complained raises a question: How honest were the confessions of women during their interviews either to Noggle or Alekseevich?

Kotz and Weir came to the conclusion that the Soviet regime tamed its citizens and that this resulted in people's collective inertness in the political life of a country. ${ }^{103}$ The absence of complaints during the interviews also relates to the passivity Kotz and Weir discussed. It is something that became one of the features of Soviet mentality - never complain, especially to an outsider. Under Stalin, one had to watch his mouth in front of his friends and even

102Noggle, 86.

103 David Kotz and Fred Weir, Russia's Path From Gorbachev to Putin: The Demise of the Soviet System and the New Russia (London and New York: Taylor and Francis Group Routledge, 2007), 149. The Authors bring an example of a questionnaire launched in 9 Soviet republics (without Armenia, Estonia, Georgia, Moldova, Latvia and Lithuania) that showed that $90 \%$ population of these republics want to continue living in a union. Despite that the majority of these people remained passive during events of 1991 and allowed higher institutions to decide their fates. 
children. ${ }^{104}$ During interviews made by Alekseevich for her book War's Unwomanly Face, published in the 1980s, women might have still been afraid of Soviet power and decided not to speak up about their difficulties. I then 1990s when Noggle's book came out, the threat of Soviet persecution was gone, however, women still preferred to avoid the topic. Women who had children were proud to talk about them and their achievements, whereas those without children rarely discussed that fact or the reasons behind it. Among the few rare confessions about poor health are those of Valentina Chudaeva: "I have a daughter. Now grandchildren are growing up too... Of course, I wanted to have more children, but there was no health, no strength and no means for that." 105 One more from a letter of Valentina Gromova - "I am lonely. Because of the war injuries and contusions I was not able to have children." ${ }^{\prime 106}$ And Maria Kaliberda:"War stole our youth. It deprived many women of motherhood - the most important female happiness." ${ }^{107}$ All in all it is hard to estimate the number of women whose health was ruined during the war and who were never able to actually experience the main role assigned to them by the Soviet State - that of a mother. Ironically, war service which was not recognized by the state - denied women motherhood, which was recognized and rewarded by the same state.

\section{Non Marriageable Women}

Another obstacle in the way of women veterans was that men were reluctant to marry them. They respected them as soldiers, but did not always see women as potential spouses.

104Vera Dunham. In Stalin's Time: Middleclass Values in Soviet Fiction (Durham and London: Duke University Press, 1990), xii.

105Aleksievich, 121.

106Aleksievich, 123.

107Aleksievich, 191. 
From the confession of a veteran: "Yes, I killed people, but I am a man. I would take a sniper woman to a military operation with me, but would never marry her (...)No (...) I can't imagine marrying a sniper (...) We are used to think of women as mothers, brides."108 Women combatants reminded men about the war, which they were so eager to forget: "There were many beautiful girls among front line combatants (...) But we didn't not see women in them. Do you think I can marry a sibling? So, these girls were all our little sisters (...) After the dirt, lice and death we wanted something beautiful (...)We wanted to forget it all. And we also forgot our girls." ${ }^{109}$ Women veterans were also advised to forget: "War ended. You fought, but now try to forget. Put on your shoes. You are beautiful (...)You have to study now, get married..."

Soviet society was convinced that women who went to war were promiscuous. It started to question women's motivation to take part in the war. Many were of an opinion that women went to front in a quest for adventures and fun. A war veteran, who married a woman veteran, heard worries from his mother, "Whom did you marry? A front line woman (...) You have two younger sisters. Who will marry them now?" 111 In order to escape humiliation of being called a marching field wife (pokhodno - polevaja zhena) or a camp follower, women veterans preferred not to publicize their years fighting on the front; they were even ashamed to wear their war medals. In 1941 Soviet state issued a medal for "Military Merits" which was awarded for saving at least fifteen people from the battlefield together with a personal weapon. When awarded to women, Soviet society unofficially called the award for "Sexual Merits". ${ }^{112}$

108Aleksievich, 94.

109Aleksievich, 95.

110Aleksievich, 153.

111Aleksievich, 128.

112Aleksievich, 95; Merridale, 241. 
Valentina Chudaeva said, "We were quiet as a mouse. We kept correspondence among ourselves, but we did not tell anyone else that we were on the front. Men were heroes, victors, grooms; they have been on a real war, but us, we were looked at with totally different eyes." ${ }^{113}$ Nina Il'jinskaya added, "Men came back from war as heroes. Grooms! But for girls things were different: "We know what You have been doing there, (...) to be frank, we were hiding, we did not want anyone to know that we were fighting on the front. We wanted to be ordinary again. We wanted to be brides." ${ }^{114}$ Nina Chirva, a World War Two veteran, remembered how a veteran flirted with her during the entire evening, until he saw her military uniform in the cloakroom and left. ${ }^{115}$ Not only were women combatants non marriageable, but they also faced a problem of finding a marriageable man. After the end of the war men were in high deficit in the Soviet Union. It is estimated that there were seven million more women than man in the Soviet Union in 1939, whereas in 1959 the amount of women exceeded that of men by twenty million. ${ }^{116}$ Such extreme demographic imbalance clearly implies competition between the women and promiscuousness among men. If in 1945 280, 000 single mothers applied for a state support, then in 1950 that number skyrocketed to $1,700,000 .{ }^{117}$ No matter how much the Soviet state wanted women to marry and have children, due to the demographic situation, millions of women found it impossible to find a man.

In the post-war Soviet society women outnumbered men by millions, and it is therefore ironic, that just female combatants and not male, had a reputation of being free lovers. It seems that being called promiscuous, while men were worshiped as heroes, was a very painful

113Aleksievich, 119.

114Aleksievich, 223.

115Aleksievich, 225.

116 Linz, 19; Smith, 279.

117 Smith, 282. 
memory for women veterans. The absolute majority of women, who took part in Great Patriotic War, did that on a volunteer basis. Their motivation was not fun nor adventures. These were women who wanted to protect their Homeland from foreign invaders and support their husbands, sons and fathers. The passion and loyalty they fought with is impressive. Ljuba Zemskaja, heroine of the Great Patriotic War, says: "If enemy's shell rips off one of my hands, I will fight with the one that is left. If I lose my leg in the battle, I will crawl to the enemy lines and bomb these wild beasts up. If they gouge my eyes, I will see the enemy of the Homeland with my heart, and believe me I won't miss!"118 The contribution of the Soviet women combatants to the warfare of Second World War is unprecedented in history. But instead of hearing gratitude for it, women veterans heard insults. ${ }^{119}$ Most importantly, apart from ignoring women's military achievements and recognizing their contribution to the front lines, the Soviet state also deprived them from their most promoted roles of a mother and a wife.

\section{Psychological effects}

War devastates and exhausts people. Winning it does not necessarily imply a dearth suffering from the consequences. Because of its totality, that is especially true in regard to the Second World War. As Tumarkin rightly underlined, the post-war years in the victorious Soviet Union were at least as devastating as in defeated Japan and Germany. ${ }^{120}$ Because of the refusal of the Soviet state to take care and deservedly honor the participants of the Second World War, I would even ague that the victorious Soviet people were worse off than people in defeated Axis states. As Zubkova concludes the postwar years in the Soviet Union were so devastating

118Murmantseva, Sovetskie Zhenshchiny v Velikoü Otechestvennoŭ Voĭne, 126. 119Aleksievich, 280.

120 Tumarkin, 96. 
both emotionally and physically, that most people who lived during 1940s and 1950 did not distinguish between war and postwar periods. ${ }^{121}$

The last reason that explains why war-time experiences of women were neglected was - according to Gregory Smith - pure fatigue. ${ }^{122}$ It seems that women were so exhausted and happy that the war was finally over, that they did not have strength to start another war with the state to gain official recognition of their heroic war deeds. They were just happy to return to their factories and live in a peaceful society. ${ }^{123}$ The war was complicated enough and it is understandable, that upon its end, women wanted simple, at times even primitive, things "After the war ended I had three wishes: first - finally I will stop crawling and start taking trolley buses, second - I want to buy and eat the whole loaf of white bread, third - I need to have a good sleep in a bed with white crackling bedlinen." ${ }^{124}$ Additionally there was no time to reflect on the past, since the new postwar goals were set at such an instant pace. Hunger, persecution, lack of workers, millions of handicapped people, destroyed cities and families were all among the problems postwar Soviet society faced. One might assume that as the war ended, men came back from the fronts, and thus made women work less. However, in the reality responsibilities of women only increased. By the end of 1945, women still constituted $63 \%$ of the total workforce in Moscow. ${ }^{125}$ Now they had to combine the labor front with the home front and take care of the sons, fathers and husbands, who were crushed after the war. Following an eighteen hour workday, women simply did not have energy nor desire to go and

121Elena Zubkova, Russia After the War: Hopes, Illusions, and Disappointments, 1945-1957 (Armonk, NY: M.E. Sharpe, 1998), 101.

122Smith, 333.

123Noggle, 125.

124Aleksievich, 66.

125 Gregory Smith, 333. 
fight the state for any sort of recognition. "Maybe that is why we did not have much post combat stress - we did not have time to reflect on our personal experiences in the war, we were too occupied by the present", said night bomber pilot Nadia Popova. ${ }^{126}$

\section{Wartime Trauma}

For the majority of people youth is often the best period in life. The human brain tends to concentrate memory on the good things and forget about the bad ones. It seems that this rule has no exceptions, no matter how hard one's youth was, he/she still feels nostalgic about it. Women combatants of the Second World War, girls whose hair turned gray at the age of nineteen, confirm that, "Those were our finest hours, the most brilliant times of our lives, ...for our generation the memory of the war is a holy memory." ${ }^{127}$ Still, the main message, one has to keep in mind when researching war-time experiences, was expressed by Ol'ga Omel'chenko, "I won't believe anyone, who would say that he was not afraid of the war." ${ }^{128}$ War is a horrible destructive event that has an enormous impact on people's personalities and further choices in life. Therefore, that "holy memory" of war seemed to bring more illnesses to women than they were able to bear. "I came back from the war alive, but I was ill for a long time. I was ill until the moment I told myself that I have to forget about everything that happened to me.. I even feel sorry that such a young woman like you [Aleksievich] wants to know this."129

The choice either to remember the war or to forget it was done individually by every woman. Instead of being united and dealing with their memories collectively, each one

126Shelley Saywell, Women in war (Markham, Canada: Viking, 1985), 137.

127Stites, 204.

128Aleksievich, 139.

129Aleksievich, 37. Interview of Ljubov' Zaharovna. 
struggled with individual memories and horrors of the past war. In War's Unwomanly Face Svetlana Aleksievich collected sincere confessions that clearly indicate how problematic it was for women veterans to forget the war and go on with their lives. Testimonies suggest that women veterans were suffering from wartime traumas. Among other symptoms were insomnia - "After the war we had a lot of headaches, could not relax, and had very hard problems with our sleeping;" ${ }^{130}$ nightmares - "I kept going on my secret operations for fifteen years more after the war. Every night...I saw those dreams: either my gun malfunctioned or we were surrounded by the enemy... And then I woke up - teeth chattering;" 131 selective memory - "...I completely forgot the names of the girls who were with me, and for twenty years I tried to remember;" 132 as well as various phobias - After being tortured by Germans on the electrical chair, Ljudmila Kashichkina confesses, "I can't stand electricity ever since...I can't even iron now...That feeling stayed with me for the rest of my life...Did we need psychotherapy after the war? I don't know." The woman started to cry and added, "But that is how my life passed."133

All such testimonies show that just as painful it was to remember the war, it was just as painful to forget it. All of these women needed help from professional people who would ease the process of returning to normal civilian life. The much discussed topic in the West of the post-war trauma disorder, however, did not even exist in the Soviet dictionary. Instead of being approached from a medical point of view, the issue was avoided. The topic of distress and shock that soldiers witnessed on the battlefields was considered a taboo. ${ }^{134}$ There is no Soviet

130Noggle, 47. Interview of Serafima Amosova-Taranenko.

131Aleksievich, 66.

132Noggle, 79. Finally on the twentieth anniversary Senior Sergeant Matryona Yurodjeva - Samsonova was able to recognize and remember her war friends.

133Aleksievich, 259.

134 Merridale, 17. 
book on the Second World War that includes discussions of rape, stress, cowardice, fear of death or self-mutilation. ${ }^{135}$ More then that, veterans claiming to have war traumas were supposed to feel ashamed. ${ }^{136}$ The official line of the state was that if a person was unable to overcome any mental or physical disabilities that he received as the result of the war, then that was the fault of that individual, rather than of the state. ${ }^{137}$ Neglected, ashamed and exhausted women veterans became double victims of the Great Patriotic War. Sometimes their morale was so low that they wished they would have died during the war, "I envy my friends who died in the war. I envy that they left this life without having lost their faith, without becoming disillusioned." ${ }^{\prime 13}$ Wartime traumas accompanied women veterans their entire lives. The extent to which individual women were troubled by this trauma varied, in the same way as everyone's wartime experiences did. But nothing meant forgetting, and as partisan Vera Odinec concluded, "Our generation will forget the war only when we die."139

135 Merridale, 7.

136 Merridale, 17, 269.

137 Sarah Phillips "There Are No Invalids in the USSR!"- A Missing Soviet Chapter in the New Disability, Disability Studies Quarterly (Volume 29, No 3, 2009), 7.

138 Stites, 206. From the letter of O.Golubeva, an invalid of the Great Patriotic War, published in Literaturnaia gazeta.

139 Aleksievich, 274. 


\section{The Real Heroes}

In order to understand to what extent Soviet women combatants were neglected by the Stalinist state, it is crucial to analyze what happened to the male veterans in the post-World War Two society. What kind of impact did the same factors like gender ideology, urgent need for labor and war-time traumas have on men? According to Soviet ideology the front was a masculine space, whereas the rear was a feminine one. ${ }^{140}$ As it was already discussed women also became a part of the front, but since officially it was not their sphere of activities, their front line experiences were for the most part neglected. At the same time, women's contribution to the home front - rear - were well acknowledged and recognized. Making conclusions from this pattern, one could assume that the front line experiences of Soviet men were widely publicized, recognized and awarded. Relying on women's interviews, one could assume the same - that the position of Soviet male veterans in the postwar period was much different - "Men were heroes, victors, grooms; they have been on a real war, but us, we were looked at with totally different eyes." ${ }^{141}$ Women felt like their experiences were overshadowed by men's; that men got all of the recognition, while women got none. But was that really the case, were Soviet men combatants much better off after the end of the war, compared to women? Or was it just an illusion that was created due to the considerable overbalance of men in the army?

The strict separation of men's and female's worlds was already discussed in this thesis. As much as women were supposed to perform their gendered tasks, men also had to follow their designations. It is true, that being a soldier was a task for a man, but after the war ended, 
many men felt as useless as women. The wartime feeling of a soldier that he was "holding the fate of the country in his hands", in the peacetime changed to the feeling "with me, without me, everything goes on anyway." ${ }^{142}$ At the beginning of her quest in finding the ordinary Soviet rifleman - Ivan, Catherine Merridale found that Ivan was characterless. ${ }^{143}$ The story of Soviet male veterans is the story about victors becoming victims of the regime they so selflessly fought for. So is it better to do something one is not meant to do and be abandoned (the case of Soviet female combatants) or do exactly what one is supposed to do and then be abandoned (the case of Soviet male combatants)? The truth is that both cases caused depression and humiliation. The state's neglect hit men as hard as women.

\section{Expectations and disappointments}

The total amount of demobilized men by 1948 (complete demobilization) was 8.5 million men. ${ }^{144}$ Upon demobilization veterans were entitled to the cost of the transport home, food for the journey, a set of clothes, a pair of shoes and a lump sum calculated on the basis of army pay and length of service. All of them were coming back home full of hopes for a greater future: "From now on life can only become better. We have known the worst; so there's nothing but good lying ahead." ${ }^{145}$ Peter Pirogov thus described his post-war expectations: "I was in high spirits and looked toward the future without fear. I was certain that I would be treated with respect, that my war service would be recognized, and that I would be helped to

142 Zubkova, 28.

143 Merridale, 4.

144 Zubkova, 22.

145 Snow, 12. 
find my place in life." ${ }^{146}$ Veterans expected life to be one big holiday after the war. ${ }^{147}$ But as soon as the Victory Parade was over, the next day no one sang anymore, as misery is never celebrated. ${ }^{148}$ Snow described the soldiers coming back home as "walking or hopping or stumping in between the rows of tanks were groups of white-clad, crippled veterans. There was a clear exchange in front of you, an arm or a leg or a piece of skull missing from each of these men, at the cost of the trophies taken from the enemy. Armless and legless youth with old faces, who would never forget their wounds." ${ }^{149}$ Demobilized soldiers came home and found everything and everyone gone. Some became disillusioned already on the way home. One of the demobilized soldiers expressed his concerns: "When we were healthy and fought, we were useful. But now we are crippled and nobody cares about bringing us home in a human way." 150

Pirogov witnessed a gruesome situation in one of the post-war bars. A waitress mocked a drunk veteran, who insisted that he was a hero of the Great Patriotic War. When Pirogov asked who was that man, he was told it was a professional beggar who begged for money during the day and got drunk every night. But the drunkard assured everyone that he used to be a military pilot. "Incidentally" he had a lot of war medals. An old drunk beggar turned out to be a 26 year old Lieutenant Vassin, Pirogov's war comrade. After demobilization Vassin found a good job, however since he used to be a POW, he was treated with constant suspicion. Because of the numerous attempts to identify Vassin as a spy, he argued with the authorities

146 Peter Pirogov "Why I Escaped? The Story of Peter Pirogov" (New York: Duell, Sloan and Pearce, 1950), 233.

147 Zubkova, 34.

148 Kasenkina, 129.

149 Snow, 147.

150 Edele, 24. 
and was fired. His wife left him soon after that, because after the war he was not that much of a man, either. "I'd lost everything. Gave it up for my country, for Stalin! And neither country nor Stalin gave a damn about me." ${ }^{151}$ Three weeks after the encounter with Vassin, Pirogov learned that the latter had hanged himself in the municipal park of Lvov. It is fair to assume that the situation Pirogov witnessed was not unique, but rather a widespread phenomenon in the post-war Soviet society. Veterans like Vassin maintained a miserable life without a purpose and many of them, just like women veterans, preferred to have perished in the war: "It would have been better to have died in that mass grave of the Germans." ${ }^{152}$

As Vassilij Terkin, a collective character, and an encyclopedia of the average soldier's life during the war, said, "We have all waited for that victory: now there will be plenty of white bread! But victory, like bread, was also stolen from us." ${ }^{\text {"153 }}$ For average citizens nothing changed after the war; in order to survive everyone had to work, no matter if he/she fought in the war or not. The fact of being a veteran of the Great Patriotic War did not improve one's position in the Soviet society. Only one soldier demobilized per thousand received a cow, twelve per thousand a pair of shoes, and six per thousand a piece of clothing. ${ }^{154}$ Apart from that distribution of goods and benefits was very unequal, some received much, while others nothing. ${ }^{155}$ The success of readapting to civilian life depended highly on the help of relatives and personal connections. State benefits had hardly anything to do with it. ${ }^{156}$ Even if a person worked, it was impossible to survive on one salary, it was so small, "that the only things found

151 Pirogov, 242.

152 Pirogov, 242.

153 Iurasov, 28-33.

154 Edele, 40.

155 Edele, 40.

156 Edele, 55. 
at homes were dust, shadows and trash." ${ }^{157}$ As a result, many veterans found themselves in the edge of poverty and starvation. In his book Visa to Moscow Gordey put veterans on the lowest level of the pyramid of Soviet wage earners, describing their position in the society as ,...a wounded veteran, incapacitated for work, father of several children (...) he drags out a miserable existence (...) he is badly clothed, badly fed. This extremely low standard of living is explained by the fact that no member of the family is able to work, and that a military pension is not enough to live on. ${ }^{6158}$

After the end of the war, men were persuaded to start working for the good of the state, as much as women were. Additionally to that more pressure was put on the men who came from the front; because of their heroic participation in the war, they became role models for the rest of the workers. ${ }^{159}$ New labor heroic deeds were now expected from veterans. The same qualities that were appreciated at the front, such as selflessness, courage, discipline, were now to be implemented at work. Seems like physical skills and discipline were the only thing Stalin wanted veterans to inherit from the war. All memories and emotions had to be forgotten, because in Stalin's eyes they disturbed men from concentrating on work. Veterans constantly wrote letters to the state, they asked for more freedom, education, cultural life, better housing conditions, renovation of hospitals, etc. They thought that these were the things they fought for, that they were something they deserved. However, none of these requests were ever answered nor fulfilled. ${ }^{160}$

War had the same devastating effect on men as it had on women. They too became old

157 Iurasov, 42.

158 Gordey, 107-108.

159 Edele, 35.

160 Merridale, 340. 
overnight and received gray hair in their teens. They also did not avoid the post-combat stress. In a same manner as women, men too were unwilling to remember the war and their stories were often cut short: "I was the only one from our class of all the boys who went to the front who remained alive after that war. What else is there to say?" ${ }^{161}$ For many veterans, war was the only way of life they knew. The Great Patriotic War was devastating, but at the same time structured; there was discipline, orders, most importantly meaning. In peacetime veterans were lost; they did not know how to live without rules. Uneducated, young peasants the majority of Soviet infantry, ${ }^{162}$ they went to war to protect their Homeland often as a "cannon fodder". The war was their only profession and education they only thing they were capable of doing. The situation was so extreme that many of veterans hungrily waited for another war, "If there were another war, I would go." ${ }^{163}$ Soviet gender ideology that bestowed men with qualities like courage, selflessness and manliness put a lot of pressure on the exhausted demobilized soldiers, especially invalids. The latter felt particularly useless and abandoned by everyone. Male combatants also experienced failures in their love lives. Often the gap that was created between married couples during the war proved to be to irrevocable, which resulted in separation and divorce.

All in all the victory gave nothing to the veterans except for promises and as Edele underlines, it is even hard to imagine what kind of "reimbursement" from the state would satisfy them. Many did not know how to live without orders and discipline, others were lost to the extent that they desired another war. Both sexes experienced problems in re-adapting to civilian life; both had suffered from wartime traumas and needed psychological assistance; the 161 Terkel, 459.

162 Merridale, 21.

163 Merridale, 341; Edele, 60. 
expectations and hopes about a peacetime of both sexegenders were crushed. Clearly, veteran's expectations were not met, instead of an easy peaceful time, life "became worse than the bitter radish."164

\section{Invalids}

From the interviews of women combatants one can form an opinion that no matter what, women's situation was always worse than men's: “The entire war I was afraid to lose my legs. I had beautiful legs. For men it doesn't matter much. But the fate of a crippled woman is decided." 165 But male war invalids were also hit hard. It is wrong to assume that a legless man suffered less than a legless woman. The Soviet ideology assigned men with qualities like manliness, courage, power. But how were invalids, many with amputated hands or legs, supposed to be manly? How was a man with amputated limbs able to support a family? In the Soviet state which was highly patriarchal and in which power was one of the greatest values for males, invalids felt that they failed the test of manliness. That certainly had a devastating effect on them. Some of them decided not to come back home and overburden their spouses, while others were abandoned by wives for a "better catch". The Soviet state did not even recognize the existence of invalids in the country. When invited to take part in the first Paralympic games, Soviet Union explained its absence at the games as "There are No Invalids in the USSR". ${ }^{166}$ Obviously, that was not true, but the myth of the Great Patriotic War could not have accepted the fact that war actually mutilates people and changes their lives forever. The pictures of invalids have never made it to the war propaganda posters. Society was disgusted

164 Iurasov, 24.

165 Aleksievich, 180.

166Fefelov, 121. 
by them, some felt a hidden guilt inside, but most decided to close their eyes and forget. In this way, people who were fighting and nearly died for their homeland were abandoned. They formed a separate subculture of people living in the train stations, beggars and con men. ${ }^{167}$ Was it a train ramp they were risking their lives for?

Even though all of the invalids in the Soviet Union unanimously supported the idea of creating an All Union Invalid Community, the establishment of such organization was forbidden in the Soviet Union. ${ }^{168}$ It is worth stressing, that among all the different groups of invalids, it were the war invalids that got the highest state support. ${ }^{169}$ As Edele states, war invalids were among one of the privileged groups in the post-war society. When in 1947, all of the privileges to the remaining veterans were cut, war invalids kept theirs. ${ }^{170}$ However, even such a positive development as privileges brought complications to invalids, because now women married them in order to receive benefits assigned to a wife of an invalid. ${ }^{171}$ No matter what even the highest level of state support was a ridiculous amount; it was impossible to survive solely by relying on that money ${ }^{172}$ In order to survive, invalids had to work, but due to disabilities, many were unable to find an official occupation. As a result, invalids became a big part of the Soviet shadow economy ${ }^{173}$ In its desperate need for labor, the Soviet state insisted on an annual medical examination which had to confirm that the severity of invalid's disability did not improve. In the latter case, they would start working normally. Even veterans with amputated limbs had to go through the examination, "as if it would grow back" (a grim joke

167 Edele, 93.

168Fefelov, 35 .

169Fefelov, 106.

170 Edele, 99.

171 Merridale, 367.

172 Zubkove, 24.

173 Edele, 63. 
among them). ${ }^{174}$ As a matter of fact working women were better off in the Soviet society than war invalids - an invalid's pension accounted for 180 rubles, whereas a working women's salary was 300 rubles. $^{175}$

Neither the Soviet state nor the people wanted to be surrounded by invalids. The fact is that invalids, people who were not working but who still received some financial support from the state, invoked resentment among Soviet society. People thought that veterans do not deserve to get paid for nothing. The Russian proverb - one does not eat, unless he works became a widespread motto all over the Union. ${ }^{176}$ Things went as far as deporting invalids to the outskirts of the country, so that they would not destroy the "perfect" image of the Soviet post-war society. ${ }^{177}$ The invalid veterans in the remote villages all over the Soviet Union became prisoners of their own homes. A person without legs or arms was useless for a life in the village, medical care was often unavailable and there was no one to talk to. As Merridale explains, sometimes the Soviet government would come up with some programs that would encourage invalids to take up a new profession or hobby; however, most often those were taken as an insult rather than appreciation by the invalid veterans. ${ }^{178}$ The Soviet state also set up special homes for invalids; however the general maintenance in most of them was so bad, that invalids preferred to stay at home. ${ }^{179}$

174 Zubkova, 24.

175 Edele, 71.

176Fefelov, 101.

177 Tumarkin, 98; Phillips ,7; Edele, 93-94; Merridale, 364.

178 Merridale, 364.

179 Edele, 89. 


\section{Relationships with women}

It was already discussed that men were reluctant to marry women combatants, however women also broke up their marriages with male veterans. During the war many men became insecure that their wives would not like the men they had become. ${ }^{180}$ Such fears were well justified; many couples were unable to save marriages after the war. Men who were severely injured during the war often received letters from their wifes who upon finding out about the injury, wanted to end marriages. ${ }^{181}$ Other women married invalids in order to take advantage of their privileges. Even without wartime injuries, the war had lasted for too long and had a terrible impact on married couples. One of the most influential and famous war-time poems by Konstantim Simonov "Wait for Me" invoked women's patience on the home front:

...Wait for me and I'll come back...

...They will never understand

How amidst the strife,

By your waiting for me, dear,

You had saved my life...

The truth is that many couples did not survive the war. Women, who according to Simonov's poem, were supposed to be patient no matter what, decided to move on with their lives. A letter with the content "Our flame was not hot enough to last" reached and devastated thousands of men at the front. ${ }^{182}$ Those couples that did survive the war had difficulties including together due to a very obvious four year gap between them. Some continued to live together only because of the shared property, even though the feelings were long gone. ${ }^{183}$

180 Merridale, 241.

181 Merridale, 241.

182 Merridale, 316.

183 Merridale, 369. 


\section{Why not to Recognize Veterans?}

\section{Stalin's Fear of Reform}

The discussion about the post-war realities of women combatants would not be complete without the comparative analysis of the realities of male combatants. Everything is relative, and if the situation of male veterans in post-war Soviet society was much better then it would be safe to conclude that the only reason why Soviet women combatants became a blind spot in the narrative of the Great Patriotic War was gender. However, as the analysis showed both male and female veterans felt abandoned, useless and betrayed after the end of the war. This means that gender was not the only reason why Stalin neglected veterans. This chapter concentrates on a broader problem of neglecting the war-time experiences of both male and female veterans of the Great Patriotic War. It argues that one of the main reasons why Stalin forbade veterans to publish memoirs, deprived them from the right to associate under an umbrella of a legal organization, oppressed and incarcerated many of them was his fear of any kind of revolution. Stalin knew the history of his country well - following the wars with Napoleon in 1812, there was the resistance of the Decembrists against the Tsar in 1825; emancipation of the serfs took place after the Crimean War; the revolution of 1905 was a result of the Russo-Japanese war of 1904; the October revolution took place after the First World War. ${ }^{184}$ Stalin was determined to change this pattern in the history of Soviet Union and thus made a major effort in order to prevent any new revolution.

Pirogov wondered, "If the war is over, why do people continue to talk about "the

184 Nina Tumarkin The Living and the Dead: The Rise and Fall of the Cult of World War II in Russia (Basic Books, New York, 1994), 92; Edele, 33. 
enemy?" 185 The fact was that veterans themselves now became the enemies of the state. In the immediate post-war period there were 20 to 25 million veterans (12-15\% of population) of the Great Patriotic War. ${ }^{186}$ Clearly, if united, such an amount of people could have easily overthrown any regime. In Stalin's eyes, veterans in general, and especially those who had seen the West, posed a threat to the regime. As Catherine Merridale illustrates, Stalin's fears were not unfounded. Those soldiers who have seen the West, according to the Soviet propaganda - evil Capitalist world, were impressed with its prosperity and civility. ${ }^{187}$ They noticed that women in the West existed purely for love, that the West was much more developed culturally, and that never in their lives they had so much food to eat. ${ }^{188}$ In his article"Soviet Soldiers and Officers on the Eve of the German Invasion: Toward a Description of Social Psychology and Political Attitudes", Mark von Hagen argues that Soviet soldiers were certain about the superiority of the Soviet state before the war. They believed that it was the best and most progressive place in the world. ${ }^{189}$ This kind of belief is not surprising, considering the fact that from their childhood, Soviet citizens were taught that Russians were the first ones to invent everything worth inventing. ${ }^{190}$ However, after the first encounter with the West such perceptions of the Soviet state were seriously damaged. The eventual contact with the West changed that perception completely and irrevocably, soldiers started to praise the "bourgeois lifestyle."191 Apart from admiration, experience in the West also increased veteran's expectations in regard of their future postwar lives. As Kasenkina underlines in Leap

185 Pirogov, 276.

186 Edele, 10.

187 Merridale, 346.

188 Merridale, 354.

189Thurston and Bonwetsch, 199.

190Gordey, 245.

191Thurston and Bonwetsch, 200. 
to Freedom the situation of returned soldiers - the ex-heroes - in the Soviet society was the worst. Due to Western experiences, they became the most disillusioned group of the population. The rest of the Soviet people also suffered from lines in the shops and shortages of nearly everything, but at least in comparison to the veterans they were not aware of any other way of life. ${ }^{192}$ Simonov remarked, "The contrast between the standard of living in Europe and among us, a contrast which millions of military people encountered, was an emotional and psychological shock." 193 The veterans' admiration of the Western lifestyle together with the consequent shock of the Soviet post-war realities was not something that would necessarily strengthen the socialist state. Thus in order to avoid any possible attempt of a revolution or a revolt, Stalin had to take "precautionary measures".

In order to decrease the possible threat coming from veterans, Stalin forbade them to join ranks under an umbrella of one organization. His plan was to instantly dissolve veterans as a social group. ${ }^{194} \mathrm{He}$ was interested in as little communication between the veterans as possible. Stalin did not see veterans as a group sharing common interests and thus did not see a reason why would they need to have an organization. For the Soviet state veterans were ordinary citizens who had served in an army. ${ }^{195}$ It was only in 1956 that a Soviet Committee of War Veterans was formed. According to Edele, the main goal of this institution was international propaganda. It was supposed to prove to the outside world that Soviet Union is taking care of its veterans. It was only in 1978 that veterans were assigned a legal status and the "All-Union Organization of Veterans of War and Labour" was established. ${ }^{196}$ The absence

192 Kasenkina, 122.

193 Zubkova, 18.

194 Zubkova, 24-25.

195 Edele, 156.

196 Edele, 181-182. 
of a legal status did not stop veterans from wanting to get together. After demobilization they felt different from the rest of the society and began to gather in local bars, known as Blue Danubes, all over the country. The Soviet state repressed such meetings and often arrested its participants for "anti-Soviet agitation". Relying on another poem about Terkin, it is fair to state that also invalids who earned money by singing war songs on the streets were often arrested or beaten by the authorities for "anti-soviet" agitation. ${ }^{197}$ As a result there was not much interaction between the veterans and most of the wartime friendships were limited to an annual postcard on the $9^{\text {th }}$ of May. ${ }^{198}$

One more of Stalin's "precautionary measures" was to imprison POW's, or as Edele calls them - "people marked for life". By the end of the war there were about 2.8 million POW's. ${ }^{199}$ After coming back from the war, they were accused of surrendering to the enemy; many were incarcerated into Soviet camps. The first thing each POW had to do was to go through something the regime called filtration, a procedure which was meant to detect spies, cowards and traitors among POW's. As a result some POWs were executed at once, others were sentenced to up to twenty-five years in the labor camps. ${ }^{200}$ Those POW's who were able to escape incarceration remained under constant surveillance of the state for years to come. Only in 1992 the question, whether one had been a POW during the Second World War, disappeared from the general official questionnaires of the Russian Federation. All POW's were fully rehabilitated in 1995 (some were rehabilitated before but without widespread publicity). ${ }^{201}$ POW's were also deprived of the opportunity to receive higher education or

197 Iurasov, 64-74.

198 Edele, $58-60$.

199 Edele, 102.

200 Merridale, 351-352.

201 Edele, 128; Rudiger Overmans "The Treatment of Prisoners of War in the Eastern European Theatre of 
develop a successful professional career. ${ }^{202}$

Soviet partisans also fell into the group of Soviet undesirables. The war-time slogans Glory to Our Partisans!- clearly implied appreciation of partisan contributions to the Soviet war effort. However, after the war ended, conductors of guerrilla warfare against Nazi Germany also posed a threat to the Soviet regime in Stalin's eyes. As Tumarkin argues in her article "The War of Remembrance," Stalin stood behind the events of 1944 in Vitebsk, when German tanks moved down thousands of Soviet partisans. "Glory, lent easier if dead."203

The last way in which Stalin tried to hinder the unification of veterans was to pinpoint differences between them. It was not a secret that Soviet veterans came from diverse social, cultural, ethnic, and political backgrounds. During the war these differences became more vague - soldiers were soldiers. Upon return to "normalcy" Stalin often treated veterans according to their prewar statuses. As a result some veterans (mostly officers) did achieve high posts in society, recognition and a prosperous life. The group that suffered the most were veterans who were peasants, POW's and invalids. ${ }^{204}$ Everyone was treated differently, thus creating barriers toward achieving common goals.

All of these measures help to understand how insecure, paranoiac and fragile the Soviet state must have felt in order to mistrust its own citizens so much. One did not have to be a POW to get arrested in the Soviet Union. ${ }^{205}$ People were imprisoned for statements like,

Operations, 1941-56." In Prisoners of War, edited by Sibylle Scheipers (Oxford: Oxford University Press, 2010), 130.

202 Zubkova, 106.

203 Nina Tumarkin, "The War of Remembrance" in Richard Stites, Culture and Entertainment in Wartime Russia (Bloomington: Indiana Univ. Press, 1995), 203.

204 Merridale, 21. Three quarters of Soviet infantry were peasants before the war.

205 Nikolai Litvin. 800 Days on the Eastern Front: A Russian Soldier Remembers World War II (Lawrence: University press of Kansas, 2007), 142. 
"Victory was won neither by Stalin nor the Party, but by people."206 Everyone fell under suspicion, even babies that cried non - Stalinist tears. ${ }^{207}$ In The Thaw Generation Ludmilla Alexeyeva told a story of her uncle Borya who spent fourteen hours floating at sea after his submarine was sunk by the Nazis. Upon his rescue, the man was suspected of betrayal and was not allowed to ever go on another submarine mission. The Soviet state was convinced that somehow during those fourteen hours, uncle Borya turned into a spy. ${ }^{208}$

Thus gender was not the only reason why Soviet women combatants remained a blank spot in the narrative of the Great Patriotic War. It was not particularly women that the Soviet state left in the shadow of the Great Patriotic War, but also men. Stalin was more occupied with the fear of new reforms that could come from the returning soldiers. As a result, the experiences of male combatants were also neglected. Stalin was afraid of the collective power that the veterans could obtain if united; he was afraid of the impressions they received from the West; afraid to recognize veterans as a separate social group which upon acquiring a legal status could pose a serious threat to the Soviet regime. As my research showed, Stalin's fears were well justified, and he had a good reason to be afraid of about 25 millions of veterans. These were men and women who sacrificed all to the Great Victory and upon returning home were disappointed to such an extent that some desired another war, while others wished they would have died together with their friends. Yet again, with the help of the state tools, discussed in the first chapters of this paper, Stalin was able to demobilize and tame Soviet veterans.

206 Pirogov, 276. 207 Noggle, 229.

208 Alexeyeva, 42. 


\section{The Importance of Gender in the Context of Contemporary Conflicts}

It is generally agreed that war is not something a woman should be occupied with. However, through the centuries, women have fought wars side by side with men. The knowledge about these women combatants remains minimal and the research about their postwar experiences is often considered non-existent. There are many reasons why gender segregation is crucial in the context of war. First of all, women see war from a different perspective. According to Hayton-Keeva men tend to separate war from their lives, while women integrate war stories into their physical and emotional lives, thus "War seen through women's eyes makes a different kind of war story". ${ }^{209}$ A married veteran couple, who fought together in the Second World War, confessed of experiencing two separate wars, "I tell my grandchildren her [wife's] war story, not mine. I have more military knowledge, whereas she has feelings. Feelings are always more memorable." ${ }^{210}$ Together male and female perspectives create a more holistic and true image of a conflict.

Second, acknowledging the role of gender in a war can help women to establish their new roles in the post-war society. The same way as Soviet women in World War Two were not just wifes, mothers and nurses, so too aren't the women of Vietnam, Algeria, Zimbabwe or in many other countries where women take part in various military activities. ${ }^{211}$ The victimization of women, which had taken place for centuries, continues to take place in the contemporary world. Even though more and more countries open their military services for

209 Sally Hayton-Keeva, Valiant Women: In War and Exile Thirty Eight True Stories (San Fransisco: City Light Books, 1987), I.

210 Aleksievich, 109.

211 Ilja Luciak, "Joining Forces for Democratic Governance: Women's Alliance Building for Post-War Reconstruction in Central America". In Gendered Peace: Women's Struggle for Post-War Justice and Reconciliation, edited by Donna Pankhurst (New York: Routledge, 2008). 
women, a large part of the world is still not ready to give up the traditional patriarchy. In the foreword of Gendered Peace, the director of United Nations Research Institute for Social Development (UNRISD) Thandika Mkandawire argues that post-war needs of women are still being ignored or deliberately marginalized by the policies of many states. She also stresses the importance of recognizing the role of women in the wars, and giving voice to them. ${ }^{212}$

A Gender approach to understanding conflicts is crucial in preventing additional violence towards women in the post-conflict era. Donna Pankhurst calls such a phenomenon a post-war backlash against women. It is characterized by a general "anti-women" discourse in society and a wave of violence, at times on a higher level then during the conflict, against women. Such backlash is also often accompanied with a strongly gendered notion of woman's "beautiful soul". ${ }^{213}$ Undeniably a backlash against Soviet women veterans was obvious after the end of Great Patriotic War. By stressing women's femininity, images of a loving mother and wife, the Soviet state was determined to return to pre war policies and gender perceptions. Women, who had proven themselves equally brave and selfless as men, posed a threat to Stalin's regime. What if they would start seeking equality in other things too? Such fears were well founded, women had indeed changed. Elsa Smuskevich, a Red Army sniper, confessed how the relationship between her and husband changed after the war, "He wanted to be the leader of the family and make all the decisions, but because of the war, I am a leader too, and just as capable of making decisions". 214

According to UN reports, violence against women tends to increase in the immediate

212 Pankhurst, ix-x.

213 Pankhurst, 2-3.

214 Hayton-Keeva, 160. 
post-war period. That is explained by the difficulties of soldiers to adapt to civilian life. In the introduction to her book Valiant Women in War and Exile: Thirty-Eight True Stories, Sally Hayton-Keeva remembers how she feared her own father, who was a World War Two veteran: "Easily angered, his rage was enormous (...) We were afraid of this side of him and tried never to make him angry (...) It was the soldier we feared." ${ }^{215}$ Another UN report "Not a Minute More: Ending Violence Against Women” draws an example of violence from the case when four Special Forces American soldiers killed their wifes within six weeks upon their return from Afghanistan. Apart from increased violence, another problem of the post-conflict period is the growing consumption of alcohol. Many Soviet veterans, especially invalids, who according to state's line failed the test of manliness, found their remedy in alcohol. Women, who were related to such men, suffered together with them. "She became a seamstress, married an invalid of the Great Patriotic War (he had only one leg), and had two boys. But her husband drank a lot, and they got divorced. She took it hard, cried a lot, and spent some time in a psychiatric hospital. One day she disappeared and was later found dead on the bank of the Irtysh." 216

Theoretically human rights should concern humans, meaning men and women. Unfortunately that is not always the case and often men get more access to rights than women. For instance, Stalin almost granted a right to his soldiers to rape women. Once he said to a Yugoslav diplomat Milovan Djilas, "Do you see what a complicated thing is man's soul? (...) Imagine a man who has fought from Stalingrad to Belgrade - over (...) dead bodies of his comrades, (...) How can such a man react normally? And what is so awful in his having fun 1917 to the Second World War (Princeton, NJ: Princeton University Press, 2000), 234. 
with a woman, after such horrors?"217 Instead of prosecuting Red Army soldiers for raping women in the conquered lands, Stalin approached the issue as insignificant. The act of rape during a conflict is another interesting case to research from the gender perspective. It is a fact that both men and women become victims of war-time rapes. However, the considerable majority of cases deal with women as victims of sexual abuse. ${ }^{218}$ That underlines, again, the same gender victimization that has been present in Second World War. Stalin could accept men committing a rape, referring to it as a complication of man's soul, but a discussion of a Soviet man actually becoming a victim of a rape is either non-existent or very hard to find. In many countries victims of sexual abuse feel ashamed and prefer not to report the rape, instead of fighting for their rights. Women who were raped are considered dishonored, while offenders remain unpunished. It is probably for those reasons that mass rapes continue to remain an integral part of conflicts all over the world (Rwanda, FYR, Peru, Sierra-Leon, etc). World War Two was not the only conflict which put the issue of rape and birth of illegitimate children on the agenda. During the disintegration of Yugoslavia rape was adopted as a policy of "ethnic cleansing". According to UN estimations, about 20000 women became victims of rape. And while women did not want to give birth to children conceived during an act of violence and stood for abortions as a human right, the state was more interested in pro-natalist policies. As a result, all former republics of Yugoslavia introduced new restrictions on abortions during the 1990 s. $^{219}$

217 Milovan Djilas. Conversations with Stalin (New York: Harcourt, Brace \& World, Inc., 1962), 110.

218 Allesandra Dal Secco, "Truth and Reconciliation Commissions and Gender Justice". In Gendered Peace: Women's Struggle for Post-War Justice and Reconciliation, edited by Donna Pankhurst, (New York: Routledge, 2008), 96.

219 Tanja Djuric-Kuzmanivic, et al., "Gendered War, Gendered Peace: Violent Conflicts in the Balkans and Their Consequences", in Gendered Peace,265-284. 
Women's rights are simply not given priority; more than that they are being neglected without any punishment. ${ }^{220}$ No matter if the war was won by the previous regime or if the regime has been overthrown, in the post-conflict state few are concerned about women's needs. Until this day, it is normal to find women in the most marginalized sections and disadvantageous groups of a post-conflict society. Either they are returnees with the least access of resources, neglected ex-soldiers, heads of households without support, widows, invalids or orphans. ${ }^{221}$

Women all over the world are becoming more aware of the gender injustices and numerous innovations that protect women's rights have been introduced since 1945. Among many are Women's War Crimes Tribunal, Annual World Conference on Women, Convention on the Elimination of all Forms of Discrimination Against Women, and the Declaration on the Protection of Women and Children in Emergency and Armed Conflict. All of these institutions and conferences are aimed at protecting women from gender injustices all over the world.

220 Pankhurst, 8-9.

221 Birgitte Sørensen, Women in Post-Conflict Reconstruction: Issues and Sources. War-Torn Societies Project Occasional paper No.3, June, (Geneva: UNRISD, 1998), 38 


\section{Conclusion}

The story of women combatants remains under-researched in the historiography of the Second World War. That is true not only in regard to Soviet women combatants, but also in countries like Yugoslavia, Israel, Vietnam and to some extent also Germany and Britain, women veterans shared the destiny of becoming the invisible combatants. There are many reasons to consider research, undertaken during the existence of Soviet Union unreliable. Either the statistics in it are wrong, or it ignores women, or it interviews people who are afraid to say a single word wrong. After the collapse of Soviet Union, there has been an opportunity to conduct new research and draw on information from newly opened archives. During the last decades, the research on the Second World War became more intense. Many previously taboo topics, like sexual relations between male and female combatants, slowly started to come out, however the topic of the post-war lives of veterans, especially women, remains untold. New research has had a varied impact on women veterans. On the one hand, there are those who are not able to continue living with the new truth, ${ }^{222}$ but on the other hand there are also positive developments. The new information makes even the most faithful patriots of socialism reconsider their beliefs,

Even after being imprisoned I only desired to prove that I was a genuine Soviet girl, honest and loyal...My faith was boundless. Now that we all know the real truth about what happened during those times - the system that caused it, the horrors and the crimes committed during Stalin's reign, the millions of people victimized and murdered - I cannot perceive how shortsighted we were, how Stalin managed to charm and hypnotize the whole country. It's beyond my understanding. ${ }^{223}$

222 Cottam, 252 - A case of Yulia Drunina who was unable to cope with the new contempt of the World War Two and committed a suicide.

223 Noggle, 230. 
With each year veterans decrease in numbers and it will be unfortunate if the only account of their lives and sacrifices that is to be left will come from the blind believers of Stalin era propaganda. There is definitely another side to that story that deserves to be acknowledged.

With the help of existing historiography, this study researched the post-war realities of Soviet women combatants. It demonstrated that even though Stalinist state did not encourage participation of women in the military, in emergency situation of the Second World War, it was ready to temporarily overlook certain stances considering women in the army. As a result around one million Soviet women directly participated in the war. 90 of them were awarded with the highest award of distinction in the Soviet Union - the HSU. Women courageously fought the entire war on equal terms with men, there was never any clemency awarded to them. It seems like the war's front lines were actually the only places where the well proclaimed gender equality of the Soviet Union was working both in practice and theory. Because on the front, women were literally equal to men. They fought in male uniforms, they were not offered any additional hygienic facilities, they had the same amount (if not more) of flights and missions. However, as soon as the war was over, men were proclaimed heroes, while women were politely asked to forget the services they rendered. As a result the story of women combatants remained a blank spot in the historiography of the Second World War. Soviet officials never even published the number of female casualties. ${ }^{224}$ By drawing parallels with neglecting women's rights and war-time experiences in the contemporary world, this research has proven its significance. Almost seventy years have passed since the end of the Second World War. However, marginalization of women's rights continues to this day.

224 Pennington, 125 
This paper analyzed the reasons why Soviet women combatants remained a blank spot in the narrative of the Great Patriotic War. First of all, the Soviet state, as a traditionally patriarchal entity, established very distinct gender roles. There was a clear distinction between women's work and men's work and gender designations. Men were protectors and leaders of the country, whereas women were keepers of the household. War was simply considered unnatural for a woman. Theoretically women were considered equal with men from the times of Bolshevik Revolution in 1917, and Stalin tolerated a certain amount of women specialists in some traditionally masculine spheres, such as aviation. However due to the state's gender ideology, he was never planned to mobilize such a great number of women in peace time. ${ }^{225}$

The Soviet Union defeated Germany, but the price of that victory was extremely high. The country was destroyed - devastated people, burnt cities, shortages of food, workforce, housing, etc. Women, in the leading majority in 1945 , had to start rebuilding the country. Women veterans came back from the war and they were instantly occupied with rebuilding the state and starting a family. A double burden was put on them - work front as well as the home front, thus the war front simply had to be forgotten. As some of the interviewees confessed, there was no time to look back on the past, one had to concentrate on the future. Mark Edele concluded that the reintegration of veterans would not have succeeded without the contribution of women. ${ }^{226}$ After 1945 and an estimated loss of twenty million people, the majority of whom were men, Stalin urgently sought to increase the Soviet population. Thus the dominating image of the Soviet woman in the post-war society was that of a mother. In order to encourage motherhood, Stalin introduced a couple of awards that honored mothers of many

225 Pennington and Erickson, 153.

226 Edele, 71. 
children. However, due to consequences of the war and prejudices of the Soviet society, many women were unable to fulfill their main gender designations of a mother and a wife. Health problems made it impossible for some women to have children, men were reluctant to marry women veterans, and society was questioning their true motivations for participating in the war. Thus women became double victims of the Great Patriotic War.

Finally, the psychological effects of the war had a great impact on women. They were crushed, isolated and left alone for everyone to individually deal with personal war-time memories. Stalin forbade veterans to publish memoirs, and there was no veteran organization which would allow women combatants to join and share their war-time experiences. In 1948 Stalin even demoted $9^{\text {th }}$ of May, the Victory Day, from a state holiday to an ordinary day. ${ }^{227}$ Stalin was ready to close the chapter of the Great Patriotic War in the history of the Soviet Union and move on.

As this thesis demonstrated women were not the only combatants whose war-time experiences were neglected. Also male veterans of the Great Patriotic War became victims of the Stalinist state. They did not receive any more recognition than female combatants. Maybe it seemed that they were proclaimed "heroes" more often, but in practice such proclamation brought nothing with it. The reason why women felt men were more recognized as soldiers, while they were not, was most probably caused by women's relatively small number in the army. Being a soldier, protector and a fighter was a role of a Soviet man, thus Stalin glorified heroic deeds of Soviet male soldiers. However, all of that was done on a surface level and apart from selected individuals (exactly as it was in womens case), millions of men remained

227 Only under Khrushchev did the $9^{\text {th }}$ of May again became a national holiday. 
in a shadow of the Great Victory. Promised privileges to veterans were abolished, regardless of their sex, in 1947. That concerned all veterans, except those awarded with HSU, Heroes of Socialist Labor or Cavaliers of the Order of Glory. It was simply too expensive, estimated at 3, 455, 9 million rubles a year, for the Soviet Union to afford such privileges. ${ }^{228}$

The reason behind such a collective neglect of the war-time experiences of the Soviet veterans of the Second World War was Stalin's fear of reforms. Regardless of their sex, for Stalin, all of the veterans posed a direct threat to the regime. In order to decrease the power of veterans, Stalin forbade them to publish memoirs or unite under the umbrella of a veteran organization; he also imprisoned or sent to labor camps POW's or anyone who fell under suspicion of the Soviet regime. During the Stalinist times the public remembrance of the war was banned; in order to help people to forget about the devastations of the war, Stalin cleared the streets of Soviet cities of invalids; in a fast manner he renovated the main streets of Soviet towns. St.Petersburg, at that time Leningrad, demonstrated Stalin's will to forget about the war and its consequences. In Visa to Moscow Michael Gordey expressed his surprise to find Leningrad completely renovated. According to Gordey by 1950 it was impossible to tell that only six years previously, Leningrad had suffered one of the most devastating sieges in the modern warfare. ${ }^{229}$ Gordey also found the same situation in Stalingrad and Moscow. The centers of the Soviet cities represented the myth of the Great Patriotic War - wealthy war officers, nice hotels, huge shop windows. The outskirts stood for the reality - beggars veterans, ruined housing, general atmosphere of misery and loss. Stalin created the myth of the Great Patriotic War and there was no space there for individuals. Instead of glorifying people, 
Stalin assigned Soviet cities with the statuses of heroes. During his Victory Speech in 1945, Stalin appeared reluctant to differentiate between men and women, instead he replaced gender descriptors with more neutral words like comrades, heroes, Red Army, combatants and people. This language demonstrated how much Stalin wanted to portray the victory as a collective effort. As a result not only the personal experiences of women, but also the individual stories of men (to a smaller extent) failed to receive wide-spread recognition. There were no individual heroes of the Great Patriotic War, instead all of the Soviet people were proclaimed great and victorious.

At first it might seem unusual that Stalin did not face much of the resistance on the behalf of the Soviet veterans, but taking into consideration people's fear of Stalin and general fatigue of the population, things seem more understandable. Occupied with new obligations and goals, Soviet veterans did not get the chance to fight for their rights and recognition. Everyone was exhausted. After fighting the enemy for four years, veterans had no power left to start another war, this time with the state they fought and died for. Everyone wanted a peaceful life, which they thought they deserved. One also has to keep in mind the power of the Stalinist state. It is not a coincidence that later on veterans were able to achieve much more. Under Khrushchev the first memoirs were published, and $9^{\text {th }}$ of May was reinstated as a national holiday; under Brezhnev veterans were granted privileges like going in front of the shop line or free public transportation; under Gorbachev they received legal status and for the first time got access to archives, which published the war orders from the 1940s. Under Putin the veterans of the Great Patriotic War continued to receive new benefits and privileges. It is interesting, that the more time passed from the end of the war, more and more privileges were 
given to the veterans. It might be explained by the change of governments and policies, but it also might be explained by the constantly diminishing number of the veterans themselves. It is much easier to ensure support for a million, rather then to twenty millions. But no positive developments in regard to veterans happened in the immediate post-war period under Stalin's rule. That is also the reason why exactly that period of time is the focus of analysis in this paper.

This research has demonstrated the collective neglect of the Soviet veterans of the Second World War. In the narrative of the myth of the Great Patriotic War female combatants were invisible, whereas male combatants were characterless. New proper research can change this injustice, however the recourses of primary sources are decreasing with every day. How many veterans are already gone? What does the remaining part remember after almost seventy years of silence, fear and ineffective struggle with the state? What are the chances that they will be willing to talk now? Thus it is very likely that the subject of the Soviet women combatants in the Great Patriotic War will never be researched to its full potential. 


\section{Bibliography:}

\section{Primary Sources:}

Aleksievich, Svetlana. U voiny ne zhenskoe litso; Poslednie Svideteli. Moskva: Ostozhe, 1998.

Alexeyeva, Svetlana and Paul Goldberg. The Thaw Generation: Coming of Age in the PostStalin Era Pittsburgh: University of Pittsburgh Press, 1993.

Djilas, Milovan. Conversations with Stalin. New York: Harcourt, Brace \& World, Inc., 1962.

Fefelov, Valerii. V SSSR Invalidov Net! London: Overseas Publications Interchange Ltd, 1986.

Gordey, Michel. Visa to Moscow. New York: Alfred A. Knopf, 1952.

Hayton-Keeva, Sally. Valiant Women in War and Exile: Thirty Eight True Stories. San Fransisco: City Light Books, 1987.

Iurasov, S. Vasiliı Terkin posle voiny (po A. Tvardovskomu) New York: izd-vo im. Chekhova, 1953.

Kasenkina, Oksana. Leap to Freedom New York: J.B. Lippincott Company, 1949.

Lavrinenkov, V. D. Vozvrashchenie v nebo. Moskva: Voenizdat, 1974.

Litvin, Nikolai 800 Days on the Eastern Front: A Russian Soldier Remembers World War II Lawrence: University press of Kansas, 2007.

Mizin, V. M. Snă̌per Petrova. Leningrad: Lenizdat, 1988.

Noggle, Anne. A Dance With Death: Soviet Airwomen in World War II. College Station: Texas A \& M University Press, 1994.

Pirogov, Peter. Why I Escaped? The Story of Peter Pirogov New York: Duell, Sloan and Pearce, 1950.

Terkel, Studs. The Good War: An Oral History of World War Two New York: Ballantine Books, 1984.

Tvardovskii, Aleksander. Terkin na Tom Svete Russian Language Specialties No. 32, 1963.

\section{Secondary Sources:}

Banning, Margaret Culkin. Women for defense. New York: Duell, Sloan and Pearce, 1942.

Campbell, D'Ann. „Women in Combat: The World War Two Experience in the United States, Great Britain, and the Soviet Union." In The Journal of Military History, Vol. 57 (2): 1993.

Conze, Susanne, and Beate Fieseler. "Soviet Women as Comrades-in-Arms." In The People's War: Responses to World War II in The Soviet Union. Edited by Thurston, Robert W. and Bernd Bonwetsch. Urbana: University of Illinois Press, 2000. 
Cottam, Kazimiera. Women in War and Resistance: Selected Bibliographies of Soviet Women Soldiers. Nepean, Canada: New Military Publishing, 1998.

Edele, Mark. Soviet Veterans of the Second World War: A Popular Movement in an Authoritation Society 1941-1991. Oxford, New York: Oxford University Press, 2008.

Erickson, John. "Soviet Women at War" in World Congress for Soviet and East European Studies, John Gordon Garrard, Carol Garrard, and Stephen White. 1993. World War 2 and the Soviet people. New York, N.Y.: St. Martin's Press.

Fitzpatrick, Sheila, and Yuri Slezkine. In the Shadow of Revolution: Life Stories of Russian Women from 1917 to the Second World War. Princeton, NJ: Princeton University Press, 2000.

Garrard, Carol, and John Gordon Garrard. World War 2 and The Soviet People: Selected Papers From The 4. World Congress for Soviet and East European Studies, Harrogate, 1993. New York: St. Martin's Press, 1990.

Jones, Ellen. Red Army and Society. Boston: Allen and Unwin, 1985.

Ivanova, Y.Khrabrejshie iz Prekrasnykh: Zhenschiny Rossii v Voinakh Moskva: ROSSPEN, 2002.

Kaganovsky, Lilya. How The Soviet State Was Unmade: Cultural Fantasy and Male Subjectivity Under Stalin Pittsburgh: University of Pittsburgh Press, 2008.

Lapidus, Gail Warshofsky. Women in Soviet Society: Equality, Development, and Social Change. Berkeley: University of California Press, 1978.

Linz, Susan. The Impact of World War II on the Soviet Union. Irvine: Rowman \& Allanheld, 1985.

Markwick, Roger D. "A Sacred Duty: Red Army Women Veterans Remembering the Great Fatherland War, 1941-1945". In Australian Journal of Politics \& History. 54 (3): 2008.

McDaniel, Paul and Paul Schmitt. The Comprehensive Guide to Soviet Orders and Medals. Arlington, Virginia: Historical Research, 1997.

Merridale, Catherine. Ivan's War: Life and Death in the Red Army, 1939-1945. New York: Metropolitan Books, 2006.

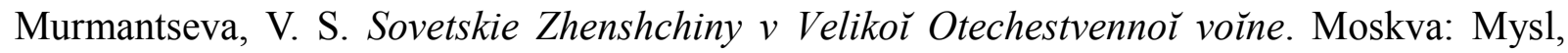
1974.

Pankhurst, Donna. Gendered Peace: Women's Struggles for Post-war Justice and Reconciliation. New York: Routledge Taylor \& Francis Group, 2008.

Pennington, Reina "Do Not Speak of the Service You Rendered: Women Veterans of Aviation in the Soviet Union". In The Journal of Slavic Military Studies, Vol. 9., No. 1., Frank Cass. London, 1996.

Pennington, Reina and John Erickson. Wings, Women, and War: Soviet Airwomen in World War II Combat. Lawrence: University Press of Kansas, 2001.

Phillips, Sarah. "There Are No Invalids in the USSR!"- A Missing Soviet Chapter in the New 
Disability. In Disability Studies Quarterly Volume 29, No 3, 2009.

Saywell,Shelley. Women in war. Markham, Canada: Viking, 1985.

Scheipers, Sibylle. Prisoners in war. Oxford: Oxford University Press, 2010

Smith, Gregory Malloy. "The impact of World War II on Women, Family Life, and Mores in Moscow, 1941-1945”. PhD diss., Stanford University, 1989.

Sokolov, Boris V. Cena Pobedy: Velikaja Otečestvennaja: Neizvestnoe ob Izvestnom. Moskva: Moskovskij Rabočij, 1991.

Stites, Richard. Culture and Entertainment in Wartime Russia. Edited by Richard Stites. Bloomington: Indiana Univ. Press, 1995.

Snow, Edgar. The pattern of Soviet Power. New York: Random House, 1945.

Suvorov, Viktor. Inside the Soviet Army New York: Macmillan Publishing CO., Incs, 1982.

Tumarkin, Nina. The Living and the Dead: The Rise and Fall of the Cult of World War II in Russia. New York: Basic Books, 1994.

Zubkova, Elena. Russia After the War: Hopes, Illusions, and Disappointments, 1945-1957. Armonk, NY: M.E. Sharpe, 1998. 